\title{
Como se escolhe um candidato a Presidente? Regras e práticas nos partidos políticos da América Latina
}

\author{
Flavia Freidenberg
}

Universidad de Salamanca

Francisco Sánchez López

Universidad de Salamanca

\section{Resumo}

Este trabalho examina a maneira como os partidos políticos da América Latina selecionam seus candidatos às eleições presidenciais. A análise está baseada no estudo de 44 partidos de 16 países da América Latina, e mostra que apesar da crescente tendência para o emprego de processos mais inclusivos na seleção dos candidatos nas últimas décadas, predomina a centralização do processo de tomada de decisões dos partidos da região. O material empírico provém da pesquisa sobre Partidos Políticos e Governabilidade na América Latina da Universidad de Salamanca.

Palavras chave: seleção de candidatos - partidos políticos - eleições internas - América Latina

\begin{abstract}
This work examines the way the Latin American political parties nominate their candidates for presidential elections. The analyses is based on a study of 44 parties in 16 countries of the region and it shows that although one can observe more inclusive procedures in the last decades, it prevails the centralized decision-making processes within the Latin American parties. The empirical material come from the research Political Parties and Governability in Latin America, Universidad de Salamanca.
\end{abstract}

Key words. Nomination of candidates, political parties, internal elections, Latin America 


\section{Introdução}

O processo de seleção dos candidatos é um campo de análise que foi algumas vezes ignorado e outras pouco explorado nos estudos sobre os partidos políticos, ainda que a questão de designar um candidato, por um processo ou outro, seja um dos momentos mais significativos em qualquer organização partidária, ${ }^{1}$ já que os indicados serão aqueles que representarão a organização perante o eleitorado e de quem dependerá muitas vezes o êxito ou a derrota eleitoral, assim como também, passada a eleição, o exercício do governo ou da oposição. Por isso, conseguir uma candidatura é um recurso de poder essencial em uma organização partidária, em particular, quando ganhar eleições se converte na meta principal para seus membros ${ }^{2}$ e a designação como candidato significa a perspectiva de um cargo político. ${ }^{3}$

A maneira como se escolhem os candidatos em qualquer partido político é fundamental, particularmente naquelas organizações em que a designação supõe competição entre os diferentes postulantes. Mas não somente nos partidos. De algum modo, a escolha de um candidato deve ser defendida perante os outros membros do partido e perante o público em geral, mesmo quando essas razões respondem a questões pessoais (amizade, família), políticas (por pressão dos grupos de poder internos ou de outros grupos de interesse) ou competitivas (porque tem mais possibilidades de ganhar dos outros partidos). A postulação de um candidato é uma decisão que compromete todos os membros da organização e conclui com a mobilização efetiva do partido. Essa decisão, depois de tomada, é legítima e vinculante, já que todo o partido deve colocar-se atrás do candidato e mobilizar-se em seu favor. Mas, sobretudo, o processo de seleção é um aspecto importante porque mostra quem é recrutado para ganhar uma eleição; ${ }^{4}$ permite conhecer a dinâmica intrapartidária ${ }^{5}$ e os momentos de maior conflito; vincula as elites partidárias, os candidatos e os eleitores entre si, ${ }^{6}$ permite observar uma das dimensões centrais da estratégia organizativa para conquistar apoios por parte dos políticos e seus partidos ${ }^{7}$ e pode afetar a disciplina dos membros no Legislativo, ${ }^{8}$ com claras conseqüências para a coesão do partido, assim como também para o

\footnotetext{
${ }^{1}$ Ver Schattschneider (1941); Gallagher (1988, p.1); Katz (2001, p.276-296).

${ }^{2}$ Entre todas as possíveis metas que um partido pode ter, há uma comum a todos, intrínseca à natureza dos próprios partidos, que é a de conseguir cotas de poder. Diversos autores de distintas perspectivas coincidem na defesa esta premissa: Weber (1992); Schattschneider (1941); Schumpeter (1962); Duverger (1951); Downs (1992); Kirchheimer (1980); Epstein (2000); Sartori (1992); Janda (1980); Von Beyme (1986); Schlesinger (1994); Billie (2001); Alcántara Sáez e Freidenberg (2001), entre outros.

${ }^{3}$ Ver Kirchheimer (1980, p.344).

${ }^{4}$ Ver Epstein (2000, 201); Gallagher (1988, p.2).

${ }^{5}$ Ver Gallagher (1988, 2); Ware (1996, p.257); Rahat e Hazan (2001), e o trabalho de Billie (2001, p.364).

${ }^{6}$ Ver Taylor (2000, p.2).

${ }^{7}$ Ver o Capítulo 2 para uma justificação teórica desta afirmação e o Capítulo 8 para uma análise empírica à luz do Partido Roldosista Equatoriano em Freidenberg (2001).

${ }^{8}$ Ver Gallagher (1988, p.265) e Mainwaring e Shugart (1998, p.164).
} 
rendimento das instituições do sistema político. ${ }^{9}$ Finalmente, a partir da observação dos processos de seleção dos candidatos, é possível compreender a maneira como funciona o sistema democrático, uma vez que é de se esperar que nesse tipo de regime as instituições também se comportem internamente de maneira democrática. ${ }^{10}$

Embora o processo de seleção dos candidatos seja um dos momentos centrais da vida interna de qualquer partido, seu estudo recebeu pouca atenção na América Latina. As razões da escassez desse tipo de trabalho são diversas. Primeiro, trata-se de um tipo de dado difícil de conseguir porque usualmente não existem registros oficiais, acessíveis ao observador externo, em que conste essa informação básica dos partidos. Segundo, existe certa tensão entre o respeito às regras formais e o que depois acontece "a portas fechadas", dificultando ainda mais esse tipo de estudo. E, em terceiro lugar, as constantes mudanças de procedimentos impedem o estabelecimento de pautas de funcionamento estáveis: não raro, um mesmo partido emprega mecanismos diversos em duas eleições seguidas, o que dificulta a análise, pois normalmente essas mudanças não se encontram registradas nos documentos partidários. Essas razões fizeram com que se subestimasse muitas vezes o estudo desses tipos de processos, mas consideramos que, embora sobrevivam regras informais que subjazem ao funcionamento formal do partido, que esses processos não se encontrem registrados de maneira específica e mesmo que muitas vezes as regras formais não são respeitadas, os políticos necessitam legitimar seus atos em função dessas regras, sempre que elas estabelecem o que se pode (e não se pode) fazer, o que se espera dos membros e a relação que deve existir entre eles. No momento de dirimir conflitos internos, as regras e, particularmente, sua interpretação, são um recurso de suma importância para definir, exteriorizar e legitimar o exercício do poder. ${ }^{11}$ Dada a importância que tem o processo de seleção de candidatos e uma vez que ele é um dos espaços que podem gerar maiores conflitos internos, é razoável pensar que esse processo deva ser explicitamente detalhado nas regras dos partidos. ${ }^{12}$ Por isso, é interessante observar os métodos que os partidos estabelecem em seus regulamentos como uma maneira (não a única) de aproximar-se do estudo da seleção dos candidatos e contrastar a história formal com a real.

Embora se tenham realizado pesquisas sobre partidos políticos específicos ou comparando partidos de diversos países, ${ }^{13}$ não se desenvolveram na América

\footnotetext{
${ }^{9}$ Ver Gallagher (1988, p.1) e BILLIE (2001, p.364).

${ }^{10}$ Este argumento é sustentado por Billie (2001, p.364).

${ }^{11}$ Análises neste sentido se encontram em Katz e Mair (1990); Panebianco (1982) e Alcántara e Freidenberg (2001).

${ }^{12}$ Billie (2001, p.365).

${ }^{13}$ Exemplo disso foram os estudos de caso como o de Coppedge (1994, p.20-24) sobre a Ação Democrática na Venezuela; o de Diaz. (2000); o de Freidenberg (2001) sobre as estratégias de seleção de candidatos do Partido Roldosista Equatoriano. Existem também estudos comparando partidos de um mesmo país, como os de Siavelis (2001) e (1997); o desenvolvido por De Luca, Jones e Tula (2000); o de Buquet (2001); o de Taylor-Robinson (2001) e o de Valdés (2001). Outros trabalhos em
} 
Latina trabalhos que abordem de maneira comparada um grande número de partidos, sistematizando os diversos mecanismos que as organizações partidárias da região utilizam para escolher seus candidatos. Foi precisamente a ausência desse tipo de análise que nos motivou a realizar esta pesquisa de caráter exploratório. Os objetivos do presente estudo se baseiam na necessidade de contribuir para a discussão sobre os mecanismos que empregam os partidos para escolher seus candidatos e de delinear uma série de ferramentas que permitam abordar a análise dos métodos de seleção de maneira comparada.

$\mathrm{O}$ trabalho divide-se em três partes. Na primeira seção, apresentam-se os distintos métodos de seleção dos candidatos dos partidos em geral e se esboçam algumas ferramentas para seu estudo. O marco analítico contempla duas dimensões que têm a ver com o tipo de candidatura e com o mecanismo de escolha dos candidatos, construído a partir de uma série de perguntas propostas por pesquisas recentes sobre este tema realizadas em outros contextos regionais. ${ }^{14}$ Neste marco, interessa-nos explorar as seguintes questões:

a) Quem pode ser escolhido como candidato? Podem ser todos os cidadãos, os militantes dos partidos ou os militantes que cumprem uma série de requisitos? Há restrições na apresentação das candidaturas? Que tipos de restrições ocorrem: de natureza interna ao partido ou de caráter externo (estabelecidas por lei)?

b) Quem escolha os candidatos: os cidadãos, todo os membros do partido ou somente alguns?

c) Onde se escolhem os candidatos? São escolhidos no nível nacional ou no nível subnacional?

d) Como são designados os candidatos: por procedimentos de votação dos cidadãos, dos militantes, de ambos, ou são diretamente designados por órgãos do partido? São mecanismos inclusivos ou exclusivos?

e) Houve mudanças nesses processos ou se mantiveram estáveis? Se houve mudanças, em que sentido foram essas modificações: para mecanismos mais ou menos participativos?

Na segunda seção exploram-se os mecanismos que 44 partidos de 16 países da América Latina empregaram na seleção de seus candidatos à Presidência da República, com a intenção de oferecer um mapa dos métodos que se

que se comparam casos nacionais, como o de Martz. (1999, p.639-659) sobre as nominações presidenciais na Venezuela e na Colômbia e a discussão de Taylor (2000) sobre os processos de seleção de candidatos e sua vinculação com o sistema eleitoral na América Latina, com especial ênfase nos casos de Venezuela, Chile, Colômbia e Estados Unidos. Finalmente, Colomer (2000) e Alcántara Sáez (2001) publicaram trabalhos sobre a realização de eleições internas na América Latina.

${ }^{14}$ Ver os trabalhos de Rahat e Hazan (2001) e Billie (2001) à luz das experiências dos partidos europeus e o trabalho clássico de Gallagher (1988). Algumas das perguntas que orientam nossa investigação estão plasmadas no trabalho de Rahat e Hazan (2001) em sua tentativa de sistematizar os métodos de seleção de candidatos e o de Billie (2001) sobre os distintos níveis territoriais de seleção. 
desenvolveram nos partidos da região a partir do marco analítico exposto na primeira seção. Analisa-se o nível de inclusão que se supõe que esses processos desenvolvam e o grau de centralização (ou não) dos mesmos, o que permite discutir a questão da democracia interna dos partidos e estabelecer se houve, ou não, uma tendência para a democratização dos procedimentos dessas organizações nas últimas décadas na região.

O material empírico deste trabalho faz parte de um projeto de pesquisa mais amplo denominado Partidos políticos e governabilidade na América Latina, dirigido por Manuel Alcántara Sáez e financiado pela Comissão Interministerial de Ciência e Tecnologia da Espanha. Os critérios de escolha dos partidos analisados correspondem aos dessa pesquisa, dentro do "critério de relevância" utilizado por ela. ${ }^{15}$

\section{Mecanismos de seleção de candidatos}

O processo de seleção dos candidatos está relacionado com o processo de tomada de decisões de uma organização partidária; com a estrutura de autoridade da mesma, assim como com fatores vinculados ao sistema político. Por um lado, o tipo de processo utilizado mostra a natureza e a fortaleza da relação entre elites e candidatos. Diferentes métodos refletem distintos tipos de laços entre os participantes e manifestam intenções diferentes com respeito ao que se espera das relações intrapartidárias. Por outro lado, é necessário levar em conta que a relação entre elites e candidatos pode estar mediada por uma série de elementos. A presença (ou não) de regras eleitorais nacionais que determinam o modo como se devem escolher os candidatos, o tipo de estrutura de voto vigente no sistema eleitoral, a organização de governo, a cultura política, a natureza do partido, o tipo de liderança e as características sociopolíticas do entorno do partido são aspectos que podem chegar a incidir nesse processo de seleção. Esses fatores podem afetar a capacidade das elites partidárias de determinar o nome do candidato frente à capacidade dos eleitores de modificar essas preferências e, embora consideremos central sua análise, devido ao efeito que cada um deles pode ter sobre a variável em estudo e abordemos alguns aspectos da relação entre normas eleitorais e processo de eleição, esses fatores serão tratados de uma maneira mais profunda em

\footnotetext{
${ }^{15}$ Um partido político foi considerado relevante quando: a) havia obtido representação na Cámara de Deputados Nacional nas três últimas eleições legislativas (força numérica expressa em assentos ou em votos obtidos); b) havia superado a barreira dos cinco por cento eleitoral nas três últimas eleições legislativas; c) tivesse representação em todos os distritos eleitorais do país (força territorial) ou que sua representação em determinados distritos fosse significativa e d) contasse substantivamente na dinâmica partidária do sistema político. Entende-se por "contar substantivamente" o fato de que esse partido exerça uma influência especial na dinâmica partidária e que por diversas razões seja impossível não o levar em conta no momento de estudar o funcionamento do sistema de partidos. Embora a pesquisa original trate de 18 países, no presente estudo só se analisam 16, ficando de fora o Brasil, devido à dificuldade para conseguir informação sobre este ponto, e a Venezuela, devido às mudanças partidárias que experimentou nos últimos anos.
} 
pesquisas futuras. Nesta seção interessa-nos estabelecer um marco analítico a partir do qual possamos esclarecer as distintas maneiras que um partido político tem para escolher seus candidatos, assim como também uma ferramenta que sirva para construir uma taxonomia dos sistemas de escolha de candidatos nos partidos da América Latina.

\section{Candidaturas}

Uma das dimensões a considerar na análise dos métodos de seleção é a relacionada com quem pode se apresentar como candidato nas eleições gerais. ${ }^{16}$ Há duas maneiras de interpretar essa dimensão. Uma, é observando-a a partir do que disponha a lei eleitoral nacional com respeito a quem pode ser candidato e a outra, conforme o que indique o partido. A vigência da norma eleitoral incide sobre a natureza dos candidatos que se permitem aos partidos; o que faz com que ambas estejam relacionadas entre si, toda vez que os partidos estão condicionados pelas regras do sistema.

As restrições com respeito aos requisitos que um candidato deve cumprir para poder ser designado podem ser classificadas em um contínuo que vai desde um nível maior de inclusão até outro que supõe uma maior exclusão no processo de seleção de candidatos. Sob essa dimensão, conforme o que estipulem as normas do partido, a variável pode apresentar diversos valores que vão desde incluir todos os cidadãos, os membros dos partidos ou somente os membros dos partidos que cumprem uma série de requisitos (ver Tabela I). No caso em que todos os cidadãos podem apresentar-se como candidatos, se supõe que o processo é mais amplo e inclusivo que nos outros, que estariam no extremo oposto do contínuo, onde somente podem participar os membros do partido que cumprem uma série de requisitos, tais como, por exemplo, os que são membros há um determinado tempo; os que foram eleitos para outros cargos de representação popular; os que exerceram cargos em algum órgão interno do partido e demonstrem sua condição de quadro; que sejam assinantes do periódico partidário; que seus filhes freqüentem escolas do Estado, em vez de escolas religiosas, ou que suas esposas e filhos participem de organizações femininas ou juvenis do partido, entre outros. ${ }^{17}$

\footnotetext{
${ }^{16}$ Ver a proposta de Rahat e Hazan (2001, p.301).

${ }^{17}$ Alguns dos requisitos mencionados foram extraídos como exemplo dos exigidos pelo Partido Socialista Belga. Ver Rahat e Hazan (2001).
} 


\section{TABELA /}

Quem pode ser candidato conforme o grau de inclusão?

Maior inclusão

Maior exclusão

\begin{tabular}{c|l|l|l|l}
\hline Todos os cidadãos & & Membros partidários & & $\begin{array}{c}\text { Membros dos partidos com } \\
\text { alguns requisitos }\end{array}$ \\
\hline
\end{tabular}

Fonte: Rahat e Hazan (2001:301).

\section{Processo de designação}

A segunda dimensão para poder ordenar os métodos de seleção partidária é a vinculada com o corpo que escolhe os candidatos. Pode ser uma pessoa, um grupo de pessoas, todos os membros da organização ou os potenciais votantes. A eleição de um ou outro mecanismo supõe diferentes processos de tomada de decisões no interior do partido, assim como dá uma idéia dos tipos de relações que se geram entre os atores intrapartidários. Por exemplo, a realização de eleições internas manifesta um nível maior de inclusão de atores nesse processo decisório, enquanto que a escolha por um único líder, que concentra o monopólio da decisão das candidaturas, marca uma estrutura de autoridade menos participativa que a anterior e mais rígida, embora haja competição entre os candidatos para ganhar a vontade do líder. A natureza dessa relação é crucial, já que ajuda a conhecer o vínculo entre as elites partidárias e os futuros governantes, caso ganhem a eleição, e entre as elites do partido e os militantes. Neste sentido, não é o mesmo, para poder ser designado, que um político dependa de seus votantes ou de seu partido. No caso em que a definição da candidatura esteja nas mãos do partido, o aspirante precisa cair nas graças dos líderes, o que contribui para a disciplina interna. Ao passo que se sua nominação depende somente dos votantes, importa menos sua relação com o aparato partidário, embora este continue controlando a estrutura de oportunidades. No entanto, a escolha de um ou de outro depende, como já se mencionou, não apenas da estrutura de autoridade interna, mas também dos incentivos vigentes no sistema eleitoral.

Os métodos podem ser classificados de diversas maneiras, conforme o critério utilizado. ${ }^{18}$ Nesta pesquisa, os métodos são classificados segundo o grau de

\footnotetext{
${ }^{18}$ Rahat e Hazan (2001, p.304) apontam distintos métodos, conforme quem realiza a escolha dos candidatos: a) o eleitorado; b) os membros do partido; c) uma agência partidária escolhida; d) uma agência partidária não escolhida ou e) o líder do patido. Por sua vez, Billie (2001, p.367) introduz a subdivisão territorial em sua clasificação e distingue entre os órgãos nacionais e os subnacionais, conforme o procedimento de nominação. Taylor $(2000, p .4)$ sistematiza diferentes processos de seleção de candidatos: a) a seleção através das elites partidárias (por um único líder ou uma liderança coletiva, tanto unificada como dividida); b) a seleção a partir da realização de uma Convenção do partido ou outras organizações dos
} 
inclusão que supõem no processo de tomada de decisões do partido. Em um extremo do contínuo, o mecanismo implica um alto nível de inclusão, toda vez que o partido consulta o eleitorado ${ }^{19}$ nas eleições internas sobre quem deve ser o candidato, enquanto que no outro extremo é somente um líder que escolhe. Entre esses dois pólos, existem múltiplas possibilidades que geralmente variam entre partidos de um mesmo país, entre países e entre um mesmo partido en dois momentos distintos. Conforme seja então o nível de inclusão, são distintos os envolvidos na nominação: pode ser todo o eleitorado, através de uma eleição direta (internas abertas); somente os membros registrados no partido (internas fechadas); um órgão interno ou pela designação do líder ou dos líderes do partido (nacionais e/ou locais) (ver Tabela II).

A realização de eleições abertas supõe um maior nível de inclusão dos cidadãos no processo de tomada de decisões de um partido e sua utilização é vista pela opinião pública e alguns analistas como um indicador de democratização partidária. ${ }^{20}$ Os argumentos a seu favor indicam que este mecanismo supõe uma maior participação dos cidadãos na vida interna do partido, o qual muitas vezes os aproxima da organização e gera uma maior racionalização e ordenação dos procedimentos da classe política, toda vez que limita seu acionar à vontade do eleitorado potencial. Esse tipo de método ajuda a atrair novos membros para a agrupação; contribui para que o partido mobilize (e se preocupe) por novos interesses sociais até o momento não representados, embora isso suponha encorajar a adoção de estratégias eleitorais do tipo "catch all" e, finalmente, é um mecanismo que facilita a legitimação perante a opinião pública, ${ }^{21}$. Não obstante, costuma-se criticar os procedimentos orgânicos por sua submissão às decisões das elites e por seu papel de cenário de legitimação das decisões de uma minoria.

Mesmo assim, esse mecanismo traz ao partido uma série de dilemas. O primeiro deles tem a ver com o fato de que o tipo de eleitorado que participa das eleições internas pode ser muito diferente do que depois vai votar na disputa eleitoral, o que pode levar a apresentação de um candidato que posteriormente não seja da preferência de todo o eleitorado. O segundo dilema está relacionado com o fato de que esta prática pode servir para colocar por plebiscito o candidato acima da organização partidária, consolidando dessa forma um líder por cima do partido. Desse modo, um dos problemas mais importantes da região, a personalização da

partidos; c) a seleção a partir de eleições (fechadas, abertas, não obrigatórias) e, finalmente, d) a seleção a partir da autoeleição (self-selection).

${ }^{19}$ Neste ponto é necessário fazer uma distinção importante com respeito ao que se entende por eleitorado. O fato de que seja o "eleitorado" que elege o candidato não tem que ver com a estrutura do voto (sistema de listas abertas), mas com o procedimento interno do partido. Nesta pesquisa, se entende como "escolha pelo eleitorado" a realização de eleições internas abertas em que todos os cidadãos têm direito de participar. Para uma discussão sobre as diferenças na definição do que significa o "eleitorado" ver Rahat e Hazan (2001, p.302) e Gallagher (1988a).

${ }^{20}$ Ver as análises de Taylor (2000) e Alcántara Sáez (2001) sobre essa questão.

${ }^{21}$ Ware (1996, p.266). 
política, se agravaria. ${ }^{22}$ O terceiro dilema está relacionado com a autonomia partidária. Os mais ortodoxos assinalam que se um partido é a "parte de um todo", em seus assuntos internos deveriam participar somente aqueles que fazem parte dele. Em quarto lugar está a questão da competição interna, a mobilização de recursos e o risco da faccionalização interna. Além disso, corre-se o risco de que se privilegie o candidato que representa os valores do eleitorado (ou do que as pesquisas assinalam desse eleitorado), em vez de as preferências de seus militantes. Isso potencializa a ambigüidade programática e faz com que os candidatos busquem evitar declarações ideologicamente demasiado precisas.

\section{TABELA //}

\section{Quem escolhe os candidatos segundo o grau de inclusão?}

\begin{tabular}{c|c|c|c|c|c|c} 
Maior inclusão \\
\hline $\begin{array}{c}\text { Eleitorado } \\
\text { (internas } \\
\text { abertas) }\end{array}$ & $\begin{array}{c}\text { Membros do } \\
\text { partido } \\
\text { (internas } \\
\text { fechadas) }\end{array}$ & $\begin{array}{c}\text { Seleção por } \\
\text { órgão colegiado } \\
\text { do partido }\end{array}$ & $\begin{array}{c}\text { Seleção por órgão } \\
\text { executivo do } \\
\text { partido }\end{array}$ & \multicolumn{2}{c}{$\begin{array}{c}\text { Liderança } \\
\text { partidária }\end{array}$} \\
\hline
\end{tabular}

Fonte: Elaboração própria a partir de Rahat e Hazan (2001) e Billie (2001).

\section{A seleção dos candidatos presidenciais nos partidos políticos da América Latina}

\section{Quem pode ser candidato...}

A observação do variado cenário partidário da América Latina mostra que quem quer ser candidato deve cumprir, de um lado, os requisitos da lei eleitoral nacional e, de outro, os que lhe impõe cada partido. As leis eleitorais dos países da região estabelecem que todos os cidadãos têm o direito de eleger e, ao mesmo tempo, de ser eleitos para cargos de representação popular, com o que se costuma entender que todos os cidadãos podem ser candidatos, mesmo quando tenham que cumprir com uma série de atributos para exercer um cargo (nacionalidade, idade, não ter causas penais pendentes, entre outros). Essa particularidade ocorre em todos os países analisados, mas há alguns poucos que acrescentam a esses requisitos exigidos por lei o da filiação partidária ou o de representação territorial nacional (Chile). Neles, a própria lei eleitoral obriga qualquer pessoa que queira apresentar sua candidatura que o faça através dos partidos políticos. São os casos

\footnotetext{
${ }^{22}$ Ver Alcántara Sáez (2001, p.21).
} 
em que se dá o monopólio da representação política às organizações partidárias, impedindo que o cidadão que não seja membro de um partido se apresente como candidato em uma eleição (como em El Salvador e no Equador até 1996), o que afeta as regras internas dos partidos. Amparados nessas condições, os agrupamentos partidários esperam que seus candidatos cumpram os requisitos da lei, assim como também exigem, pelo menos em seus estatutos, que sejam filiados ao partido, embora o processo de filiação seja um mecanismo facilmente "controlável" pelas elites partidárias, caso queiram apresentar um candidato não afiliado. ${ }^{23}$

Em alguns partidos, aos requisitos estipulados por lei e ao de filiação, acrescenta-se outra série de exigências, como a de antigüidade na filiação - por exemplo, nos casos da UCR (Argentina); PUSC (Costa Rica); PC (Paraguai); PDC (Chile) - ou muitos outros requisitos, como no PRI do México, que também exige o pagamento de cotas, ter exercido outro cargo de representação popular em nome do partido, estar filiado ao partido há pelo menos dez anos; apresentar um programa de trabalho perante um órgão do partido; não ter causas judiciais pendentes nem ter sido um quadro destacado de outro partido antagônico, entre outros.

Finalmente, temos os partidos que competem em sistemas onde se permite a apresentação de candidaturas de membros dos partidos, de independentes e de auspiciados, isto é, de pessoas que não pertencem ao partido, mas que são apoiadas por ele em uma determinada disputa eleitoral. Os exemplos mais claros nesse sentido são os do Equador depois de 1996, do Chile, com os auspiciados, da Argentina e da Bolívia, com a figura dos extrapartidários, do Uruguai e do PRD do México, que permite a apresentação de candidatos externos. Enquanto isso, no Peru ocorre o caso inverso: para poder apresentar uma candidatura fora das organizações políticas tradicionais, é preciso contar com um grupo político que patrocine o candidato e uma quantidade de assinaturas de cidadãos que a respaldem. Isso significa que é possível que uma pessoa independente se apresente como candidato, mas para isso necessita "fundar" um grupo político que a apóie. ${ }^{24}$

\footnotetext{
${ }^{23}$ É interessante observar que embora este seja um requisito exigido pela organização aos que queiram ser candidatos, muitas vezes é muito fácil o processo de "filiação" quando o partido quer apresentar alguém que não é filiado. Veja-se o exemplo do PJ na Argentina, em outros níveis de eleição, como no de governadores ou no legislativo, que em reiteradas ocasiões apresentou como seus candidatos políticos não partidários, como Ramón "Palito" Ortega, a quem filiou depçois que ganhou as eleições em Tucumán, ou o caso do independente Avelino Porto, que se postulou como candidato a Senador pela Capital Federal. Agradecemos a Steve Levitsky esta precisão e os exemplos.

${ }^{24}$ Este é um dos elementos que favoreceu a presença de agrupações ônibus, criadas apenas para levar um candidato à Presidência. Veja-se como exemplo o caso de Alberto Fujimori e suas diversas agrupações políticas.
} 
TABELA III

Quem pode ser candidato segundo a lei e segundo o partido?*

Maior inclusão

Maior exclusão

\begin{tabular}{|c|c|c|}
\hline \multirow[t]{2}{*}{$\begin{array}{l}\text { Todos os } \\
\text { cidadãos }\end{array}$} & $\begin{array}{l}\text { Membros } \\
\text { partidários } \\
\text { (filiação) }\end{array}$ & $\begin{array}{l}\text { Membros dos partidos com restrições } \\
\text { internas** }\end{array}$ \\
\hline & Panamá & $\begin{array}{l}\text { México (PRI: antigüidade de filiação, } \\
\text { nacionalidade própria e dos pais, ser } \\
\text { quadro do partido, pagar cotas, ter } \\
\text { desempenhado outro cargo antes etc.; } \\
\text { PRD: filiados e pagamento de cotas) }\end{array}$ \\
\hline \multicolumn{3}{|l|}{ Peru $^{1}$} \\
\hline $\begin{array}{l}\text { Argentina (filiados, } \\
\text { filiados com } \\
\text { requisitos e } \\
\text { extrapartidários) }\end{array}$ & & \\
\hline \multirow[t]{2}{*}{$\begin{array}{l}\text { Bolívia (afiliados e } \\
\text { extrapartidários) }\end{array}$} & $\begin{array}{l}\text { Costa Rica } \\
\text { (PLN) }\end{array}$ & $\begin{array}{l}\text { Costa Rica (PUSC, antigüidade de } \\
\text { filiação) }\end{array}$ \\
\hline & México (PAN) & \\
\hline \multirow[t]{2}{*}{$\begin{array}{l}\text { México (PRD: } \\
\text { filiados e externos) }\end{array}$} & Nicarágua & \\
\hline & El Salvador & \\
\hline $\begin{array}{l}\text { Equador depois de } \\
1996 \text { (filiados, } \\
\text { auspiciados e } \\
\text { independentes) }\end{array}$ & $\begin{array}{l}\text { Equador hasta } \\
1996\end{array}$ & Equador (DP, pagar cotas) \\
\hline $\begin{array}{l}\text { Chile (filiados e } \\
\text { auspiciados) }\end{array}$ & & Chile (PDC, antigüidade de filiação) \\
\hline \multirow[t]{4}{*}{ Uruguai } & Colômbia & \\
\hline & Honduras & Argentina (UCR, antigüidade de filiação) \\
\hline & Paraguai (PLRA) & Paraguai (PC: antigüidade de filiação) \\
\hline & Guatemala & \\
\hline
\end{tabular}

* Quando se coloca o nome do país é porque os casos partidários analisados respondem da mesma maneira a essa categoria. No caso em que um ou mais partidos desse país tenha uma regra distinta, se assinala a diferença.

${ }^{* *}$ Nos casos em que se assinala o pagamento de cotas não se pôde constatar se essa exigência se cumpre na prática.

${ }^{1}$ Os candidatos que queiram apresentar-se por fora dos partidos devem formar um grupo político e reunir um número de assinaturas que os apóie para inscrever a candidatura. Isso significa que os candidatos independentes devem contar com uma "legenda política" que os respalde.

Fonte: Elaboração própria a partir de PPAL (1997-2000) e pesquisas com informantes-chaves (2001). 


\section{Quem escolhe os candidatos...}

Ao analisar a dimensão de quem realiza a escolha dos candidatos na América Latina, é necessário considerar tanto variáveis exógenas como endógenas aos partidos. Se partimos da análise dos condicionamentos externos, é possível diferenciar entre dois tipos de sistemas. De um lado, estão aqueles em que o processo de seleção de candidatos dos partidos é regido pela lei eleitoral de maneira expressa (Costa Rica, Bolívia desde 1999, Uruguai desde 1999, Paraguai desde 1996, Panamá, Honduras, Guatemala e República Dominicana ${ }^{25}$ ); do outro, estão aqueles em que existe autonomia partidária para definir suas regras internas com respeito a essa questão e que, portanto, a lei não fixa mecanismos específicos para o funcionamento das organizações na escolha de seus candidatos (Equador, Peru, EI Salvador, México, Nicarágua, Colômbia e Chile).

Nos países em que a legislação regulamenta a forma de escolha dos candidatos, ela contempla que se realizem eleições internas de que participem todos os cidadãos (afiliados e simpatizantes ou independentes) (Uruguai, Argentina, Bolívia); onde só possam votar os membros do partido (Honduras, Paraguai, Panamá); que seja um órgão colegiado do partido que defina as nominações (República Dominicana e Guatemala) ou que seja o partido que escolha o mecanismo que vai usar (Costa Rica). Em alguns dos países indicados, a inclusão dos mecanismos de seleção de candidatos na legislação eleitoral nacional foi resultado de processos de reforma política realizados nos últimos cinco anos, com exceção da Costa Rica, onde é anterior, e em Honduras, que data de $1985 .{ }^{26}$ No Paraguai (1996), Panamá (1997), Bolívia, Uruguai (1999) e Argentina (2001) a incorporação de mecanismos mais participativos se deve a uma pretendida democratização interna dos partidos gerada desde a classe política (de maneira externa às organizações). Os traços comuns dessas reformas foram a inclusão de eleições internas, com controle por parte dos órgãos eleitorais nacionais, todo isso como uma maneira de aumentar o controle sobre os partidos, em detrimento da autonomia partidária, pelo menos no que se relaciona com a seleção de candidatos, um aspecto central da vida dos partidos, tradicionalmente não sujeito a condicionantes externos. O interessante de tudo isso é que em alguns países já se utilizavam esses mecanismos antes de que a lei o determinasse, como em alguns partidos do Paraguai. ${ }^{27}$

\footnotetext{
${ }^{25}$ Cabe mencionar também o caso da Argentina, onde o Senado aprovou em 2001 uma lei que regulamentava a seleção interna de candidatos nos partidos, mas como ainda não foi aprovada pela Camara de Deputados, não está em vigor.

${ }^{26}$ Embora a reforma seja de 1985 , só se pôs em prática quatro anos depois.

${ }^{27}$ ANR-PC realizou eleições internas abertas antes da reforma eleitoral de 1996. O mesmo ocorre na Argentina, onde alguns partidos realizaram eleições internas sem que esteja já vigente a lei que impõe esse mecanismo.
} 


\section{TABELA IV}

Países em que a seleção dos candidatos está normatizada pela regra eleitoral geral

\begin{tabular}{|c|c|c|c|c|}
\hline & & O que estabelece a norma? & \multicolumn{2}{|c|}{ Internas } \\
\hline & & Candidato presidencial & $\begin{array}{l}\text { Normati- } \\
\text { zadas por } \\
\quad \text { lei }\end{array}$ & $\begin{array}{c}\mathrm{Na} \\
\text { prática }\end{array}$ \\
\hline Argentina & Sim & $\begin{array}{l}\text { O Senado aprovou um projeto de lei que estabelecia a } \\
\text { realização de eleições internas abertas simultâneas } \\
(2001) \text {. Esse projeto ainda não conta com aprovação da } \\
\text { Câmara de Deputados (em fevereiro de } 2002 \text { ). }\end{array}$ & Sim & $\underset{\text { (parcial) }}{\operatorname{Sim}}$ \\
\hline Bolívia & Sim & $\begin{array}{l}\text { A Corte Nacional Eleitoral e as Cortes Departamentais } \\
\text { Eleitorais terão a seu cargo a condução dos processos } \\
\text { eleitorais internos dos partidos políticos. Para a } \\
\text { organização e condução desses processos, a Corte } \\
\text { Nacional e as Cortes Departamentais Eleitorais se } \\
\text { sujeitarão às disposições contidas no Estatuto Orgânico } \\
\text { de cada partido (Artigo } 20^{\circ} \text {.- Controle dos processos } \\
\text { democráticos internos). Os órgãos e procedimentos para } \\
\text { a nominação de candidatos estarão contidos no Estatuto } \\
\text { Orgânico do Partido. A Corte Nacional Eleitoral, na época } \\
\text { de inscrever as nominatas de candidatos, verificará o } \\
\text { cumprimento de tais disposições estatutárias (Artigo } \\
21^{\circ} \text {.- Da nominação de candidatos.- Lei de Partidos } \\
\text { Políticos de } 1999 \text { n 1983). }\end{array}$ & Sim & $\operatorname{Sim}$ \\
\hline Colômbia & Sim & $\begin{array}{l}\text { Estipula que a organização eleitoral colaborará na } \\
\text { realização de consultas internas que poderão efetuar-se } \\
\text { em nível nacional, departamental, distrital e municipal } \\
\text { (Lei de Partidos Políticos } 1994 \text {, art. 10). Estabelece a } \\
\text { realização de eleições internas abertas, ao permitir que } \\
\text { qualquer votante participe da primária de um partido, } \\
\text { seja ou não afiliado, e as incentiva com a disposição de } \\
\text { que se financiem com fundos públicos (Lei } 180 \text { de } \\
\text { 1994). }\end{array}$ & Sim & $\underset{\text { (parcial) }}{\operatorname{Sim}}$ \\
\hline Costa Rica & Sim & $\begin{array}{l}\text { Estabelece a nominação através da Assembléia Nacional } \\
\text { ou pelo método de primárias, regulando a data em que a } \\
\text { Convenção Nacional as realiza. Na normativa nacional, } \\
\text { assim como nos Estatutos dos partidos, se designa as } \\
\text { primárias presidenciais sob o nome de Convenção } \\
\text { Nacional (Código Eleitoral art. 74). Podem participar } \\
\text { todos os cidadãos que contem com um cartão de adesão } \\
\text { indicando sua simpatia pelo partido. }\end{array}$ & Sim & $\operatorname{Sim}$ \\
\hline Chile & Não & - & Não & $\underset{\text { (parcial) }}{\operatorname{Sim}}$ \\
\hline Equador & Não & . & Não & Não \\
\hline EI Salvador & Não & - & Não & Não \\
\hline Guatemala & Sim & $\begin{array}{l}\text { A Lei Eleitoral determina que seja a Assembléia Nacional } \\
\text { de cada partido (órgão colegiado) que decida a } \\
\text { candidatura presidencial }\end{array}$ & Não & Não \\
\hline Honduras & Sim & Eleições internas fechadas. & Sim & Sim \\
\hline
\end{tabular}

(continua) 
(continuação da TABELA IV)

\begin{tabular}{|c|c|l|c|c|}
\hline México & Não & - & Não & $\begin{array}{c}\text { Sim } \\
\text { (parcial) }\end{array}$ \\
\hline Nicarágua & Não & - & Não & $\begin{array}{c}\text { Sim } \\
\text { (parcial) }\end{array}$ \\
\hline Paraguai & Sim & $\begin{array}{l}\text { Estabelece a realização de eleições livres, secretas e } \\
\text { diretas em que participam todos os afiliados do partido } \\
\text { em circunscrição única nacional segundo artigo 33 do } \\
\text { Código Eleitoral de abril de 1996. }\end{array}$ & Sim \\
\hline Panamá & Sim & $\begin{array}{l}\text { A lei eleitoral estabelece que se realizem eleições } \\
\text { internas fechadas. }\end{array}$ & Sim & Sim \\
\hline $\begin{array}{c}\text { República } \\
\text { Dominicana }\end{array}$ & Sim & $\begin{array}{l}\text { Os partidos poderão designar candidatos a cargos } \\
\text { eletivos sempre que tenha sido expresso o voto } \\
\text { afirmativo da maioria dos delegados a convenções } \\
\text { regulares e publicamente celebradas (Art. 68, Lei de } \\
1994) .\end{array}$ & São \\
\hline Uruguai & Sim & $\begin{array}{l}\text { Eleições primárias abertas realizadas por todos os } \\
\text { partidos no último domingo do mês de abril anterior às } \\
\text { eleições gerais. A eleição é somente para presidente; o } \\
\text { candidato a vice-presidente deve ser escolhido pela } \\
\text { Convenção Nacional. }\end{array}$ & Sim & Sim \\
\hline
\end{tabular}

Fonte: Elaboração própria a partir de dados de PPAL (1997-2000), Alcántara Sáez (2001) e Alcántara Sáez e Freidenberg (2001).

A observação dos dados mostra que: a) existem diversos tipos de mecanismos de eleição nos partidos estudados; b) que dentro de um mesmo país podem empregar-se métodos diversos, em particular quando as regras eleitorais nacionais não estabelecem um sistema uniforme, levando os partidos a escolher o mecanismo que mais interessa às estratégias da coalizão dominante; e c) os partidos costumam utilizar sistemas diversos para as nominações de seus candidatos presidenciais em um período curto de tempo. A seguir, serão examinados os distintos métodos utilizados nos casos em análise.

\section{Eleitorado (internas abertas)}

Nos últimos anos, houve uma tendência crescente para a incorporação de mecanismos de seleção de candidatos mais participativos na região. Os partidos decidiram consultar os cidadãos para definir seus candidatos presidenciais e, com isso, tornar mais democrático o processo de tomada de decisões partidárias. Mesmo assim, e apesar dessa tendência, ainda são muito poucos os partidos que se atrevem a esse procedimento. Os casos mais proeminentes em que se usou esses métodos são os da FREPASO e da UCR na Argentina; o da Frente Sandinista 
de Libertação Nacional na Nicarágua; o do PLC na Colômbia; o do $\mathrm{MNR}^{28}$ e do $\mathrm{MIR}^{29}$ na Bolívia; o da Concertación no Chile e, recentemente, os partidos do Uruguai e o PRI no México. Esses partidos, pelo menos uma vez nos últimos anos, utilizaram esse tipo de mecanismo para escolher candidato, com resultados posteriores díspares quanto ao êxito eleitoral.

As características dos procedimentos variam entre os países e os partidos, mas o elemento singular de todos eles é que permitem que os cidadãos participem de maneira direta na designação de seu candidato às eleições gerais e impede (em princípio) que os órgãos nacionais possam afetar os resultados. ${ }^{30}$ As variações têm a ver com a maneira como se realiza o processo eleitoral. Por exemplo, se é uma eleição simultânea para todos os partidos políticos e estipulada pela lei eleitoral (como no Uruguai, onde se fez coincidir a eleição em um mesmo dia para todos os partidos, depois da reforma constitucional que substituiu a eleição por inscrições ${ }^{31}$ ), ou se somente o fazem como uma eleição individual, sem afetar o processo de outros partidos (como Argentina, Nicarágua, Colômbia e México). Outra diferença entre os partidos que realizam internas abertas é se contemplam (ou não) o acordo entre os pré-candidatos para realizar a eleição. O melhor exemplo neste sentido é o do Partido Liberal da Colômbia que contempla em sus Estatutos a realização de internas abertas (Consulta Popular) se os dois pré-candidatos chegam a um acordo entre si e com a Direção Nacional do partido. Mas se esse acordo não ocorre, é a Convenção que designa o candidato. Nas eleições de 1990 e 1994, os précandidatos concordaram com a realização de internas e assim, depois da aprovação da Convenção de 1989, César Gaviria enfrentou e ganhou de Ernesto Samper. ${ }^{32}$

\footnotetext{
${ }^{28}$ Disputaram duas listas: a de Gonzalo Sánchez Losada e a de Juan C. Durán, que tiveram seus próprios candidatos em todos os cargos, desde dirigente cantonal a presidencial, escolhendo-se mais de 17.000 cargos. Para essas eleições o partido criou seu próprio Regulamento Eleitoral que foi aceito pela Corte Eleitoral Nacional (Alcántara Sáez, 2001, p.16).

${ }^{29}$ Este partido também realizou uma espécie de eleição interna, que gerou disputas entre as correntes partidárias, mas a Corte Nacional Eleitoral desconsiderou ambos os processos, o que lhes obrigou a fazer novamente a convocação. Por seu turno, ADN e UCS ainda não realizaram eleições internas. Ver García Montero (2001).

${ }^{30}$ Neste sentido, há uma exceção importante que é a da FSLN da Nicarágua na qual, depois da Consulta Popular de 1996, os candidatos nacionais mais votados tiveram de ser eleitos de novo e ratificados pelo Congresso do partido, o que implicou, em alguns casos, na escolha de outros candidatos. Com isso se mostra a permanente ingerência das elites partidárias nos órgãos e que a pretendida legitimação dos procedimentos internos que motiva a realização de eleições internas não resulta neste caso no sentido esperado.

${ }^{31}$ Sob esta modalidade, o PN, PC e FA-EP realizaram pela primeira vez eleições internas abertas em 25 de abril de 1999 . O Partido Nacional se apresentou dividido ideologicamente entre as lideranças do ex presidente Luis Alberto Lacalle (apoiado pela corrente herrerista principal no interior do país e controladora do aparato partidário), o ex ministro do Interior, Juan Andrés Ramírez (líder da nova tendência "Desafio Nacional") e o precursor da última coalizão governamental, Alberto Volonté. A estes somaram-se com uma presença marginal o ex ministro de Relações Exteriores, Álvaro Ramos, (depois da cisão de seu setor "Proposta Nacional" da corrente "Mãos à Obra" de Volonté) e o deputado García. Lacalle ganhou as internas com uma ampla margem de 49,60 por cento frente aos outros candidatos: Ramírez (33 por cento), Volonté (10,20 por cento) e Ramos (7 por cento) (Martínez Barahona (2001). No PC concoreram dois candidatos, ganhando as eleições internas aquele que depois obteve a Presidência da República, Jorge Battle (por 55,1 por cento contra 43,9 por cento de seu concorrente Hierro). Na Frente Ampla - Encontro Progressista se enfrentaram Tabaré Vásquez e Astori, obtendo o primeiro uma ampla maioria sobre o segundo (82,4 por cento sobre 16,6 por cento). Estavam habilitados para votar 2.399.707 cidadãos e foram às urnas 1.289.817 (Fonte: http://www.uruguaytotal.com 25 de julho de 2001 15:00).

${ }^{32}$ Ver Martz (1990, p.642). "Essa consulta se fez no mesmo día das eleições parlamentares, e tinha como regra que a escolha dos candidatos fosse por maioria absoluta, e que se declarava nula se alcançasse mais de 5 por cento dos votos das listas
} 
Quatro anos depois, novamente houve acordo e o PLC convocou a Consulta Popular, quando então venceu Ernesto Samper (48,21 por cento). ${ }^{33}$ Nas duas oportunidades que se realizaram eleições internas, os candidatos do PLC que haviam competido por sua candidatura perante todo o eleitorado, foram os ganhadores das eleições presidenciais. Para as últimas eleições a presidente, não houve tal acordo e alguns dos pré-candidatos nem sequer foram à Convenção, deixando apenas dois para a escolha, um dos quais renunciou em favor do outro, Horacio Serpa, que perdeu as eleições gerais. Desse modo, o Partido Liberal Colombiano voltou a seu método tradicional de escolha: o da Convenção Nacional. É provável que a falta de acordo e a não realização da Consulta tenham influído na perda das eleições, tratando-se de um partido fragmentado.

Nos casos em que não se fizeram reformas eleitorais encaminhadas diretamente para a realização de internas abertas (Argentina, ${ }^{34}$ Nicarágua, Colômbia, Chile, México), as razões dessa abertura no processo de tomada de decisões dos partidos têm natureza diversa, principalmente de caráter endógeno, uma vez que esse mecanismo serviu tanto para resolver conflitos em torno de lideranças como para legitimar processos de decisão internos. Um exemplo da realização de internas para a definição de lideranças se encontra na Argentina, onde tanto a competição entre a FREPASO e a UCR , no marco da Aliança de 1999, como a disputa realizada em fevereiro de 1995 no interior da FREPASO entre José Octavio Bordón e Carlos Álvarez, foram motivadas pela necessidade de conformar a fórmula presidencial que apresentaria a coalizão. ${ }^{35} \mathrm{O}$ mesmo aconteceu no Chile com a definição da candidatura da Concertación de Partidos por la Democracia em 1993 e 1999. ${ }^{36}$ Um dos exemplos de eleições abertas para legitimar procedimentos internos foi o do PRI em México, que apelou para este sistema a fim legitimar seu processo interno de tomada de decisões perante o eleitorado. Isso vale também

liberais no Congresso (para evitar boicote por outros partidos). Antes, se fazia a eleição nas convenções, onde dominavam os políticos de carreira, embora se coloreaba com representantes de juventudes etc. Finalmente, os candidatos concordaram com a maioria relativa, o que levou alguns à renúncia, mas Gaviria obteve mais de 50 por cento" Em: Roll (2001).

${ }^{33}$ Também fez-se um acordo pela maioria simples. A eleição por Consulta Popular do candidato liberal à presidência em 1994 rompeu a estrutura piramidal que definia a eleição do candidato presidencial anteriormente, e que tinha como seu primeiro escalão os chefes regionais, seguidos dos chefes nacionais. Essa mudança representou uma forte remexida nas estruturas de poder do partido. Declarações de Juan Fernando Londoño, assesor do Instituto de Pensamento Liberal, maio de 1999, publicadas em: Roll (2001).

${ }^{34} \mathrm{O}$ texto indica que nas internas abertas poderão participar os filiados a esse partido e os que não tenham filiação, embora estes só possam votar nas internas de um partido. A data das eleições de todos os partidos deverá ser unificada para que se façam de forma simultânea, da maneira como se realizam no Uruguai.

${ }^{35}$ Em realidade, estas eram as segundas eleições internas abertas que se realizavam no país depois das que a Esquerda Unida havia realizado em 1989 entre Luis Zamora e Néstor Vicente. Ver Alcántara Sáez (2001, p.17).

${ }^{36}$ Em 1999, os partidos que formam a Concertación tiveram eleições internas para escolher seus pré-candidatos à Presidência, nas quais votaram somente os membros de cada partido. Tanto o PPD como o PS escolheram Ricardo Lagos, enquanto que a DC elegeu Andrés Zaldivar. Esses dois pré-candidatos se enfrentaram em eleições primárias que estavam abertas a todos os cidadãos. Depois de uma campanha bastante intensa, Lagos ganhou por uma margem muito ampla de 71,3 por cento - 985.505 votos- a 28,7 por cento - 325.821- de seu competidor (Fonte: http://www.fortunecity.de/olympia/ beckenbauer/30/chile99.htm\#resultados 31 de julho de 2001 10:48). Em 1993, o processo não foi igual porque houve acordo do PS e PPD para apoiar Eduardo Frei e evitar que a DC apresentasse um candidato mais de direita. 
para a FSLN, na Nicarágua, onde um dos princípios organizativos fundamentais é a democracia interna (Art.10, Estatutos), o que obriga a realizar eleições democráticas em todos os organismos de direção do partido, assim como para a designação de candidatos a cargos públicos, ${ }^{37}$ com a participação tanto de membros e militantes como de cidadãos não afiliados ao partido.

\section{Membros do partido (internas fechadas)}

Outra maneira de fazer com que o processo de seleção dos candidatos seja de natureza mais inclusiva é com a participação direta dos membros do partido em eleições realizadas com essa finalidade. Na prática, muitas das reformas eleitorais efetuadas introduziram o mecanismo de eleições internas fechadas como procedimento de escolha de seus candidatos. Exemplo disso são os casos do Paraguai (habilitando o Partido Colorado a utilizar esse mecanismo entre seus afiliados em 1997), do Panamá (no Partido Arnulfista em $1998^{38}$ e no PRD desde sua regulamentação, em $1998^{39}$ ) e de Honduras (a reforma eleitoral de 1985 incorporou o sistema de eleições internas para a escolha dos candidatos, mas sua realização ocorreu somente na eleição seguinte ${ }^{40}$ ). Muitos outros partidos escolheram este método, embora a lei eleitoral não exigisse sua utilização, como a FMLN de El Salvador, a partir da reforma de seus estatutos, em novembro de 2000; ${ }^{41}$ o Partido Conservador da Colômbia; o PJ da Argentina (para a disputa entre

\footnotetext{
${ }^{37}$ O Regulamento Eleitoral aprovado pela Assembléia Sandinista em 22 de outubro de 1995 estabelecia em seu artigo 8 a participação de afiliados, simpatizantes e cidadãos em geral na Consulta Popular (Documento partidário da FSLN 1995). Na Consulta de 1996, a FSLN teve a capacidade de estabelecer pelo menos 5000 centros de votação em todo o país, atendidos por maiss de 30.000 voluntários, nos quais os votantes escolheram em torno de 7000 candidatos a representantes da FSLN (Ver Santiuste Cué (2001).

${ }^{38}$ A 29 de março de 1998 aconteceram as primeiras eleições internas na historia do PA para a escolha de candidatos a presidente e vice-presidente da República. Os dois únicos candidatos foram Vallarino e Mireya Moscoso. A candidatura de Vallarino surgira por iniciativa da facção de legisladores arnulfistas dos "saltamontes". Mireya Moscoso ganhou por uma ampla margem com um total de 11.796 votos, contra 5.474 de Vallarino. Dessa vez, os níveis de participação foram muito mais elevados, alcançando 50,34 por cento dos inscritos. Em setembro de 2001, se celebrou uma nova Convenção do Partido Arnulfista, com os livros de inscrições de candidaturas já fechados desde 31 de março, e já tendo o Diretório Nacional se pronunciado a favor de Mireya Moscoso como a "candidata oficialista" do partido (García Díez , 2001).

${ }^{39}$ Em 1990, o partido começa um processo de abertura democrática, mas foi preciso esperar até 25 de maio de 1998 para que esta agrupação apresentasse ao Tribunal Eleitoral seu Regulamento de Eleições Internas, que foi aprovado pelo Conselho Diretivo Nacional do partido em 16 de maio de 1996, de acordo com as reformas dos Estatutos efetuadas pelo Congresso Nacional Extraordinário de 7 de junho de 1995. Os candidatos a vice-presidente são designados pelo candidato presidencial que seja eleito e ratificados pelo Diretório Nacional. O Comitê Executivo Nacional (CEN) se encarrega de nomear uma Comissão Nacional de Eleições Internas, integrada por sete membros, que dirige, fiscaliza e coordena o processo de eleições internas. Ver Regulamento de Eleições Primárias do PRD (art. 4). O procedimento de eleição é o maioritário, sem limitações em termos de porcentagens mínimas de participação (García Díez, 2001).

${ }^{40}$ Nas convocações de 1989, 1993, 1997 e 2001, o PLH e o PNH realizaram eleições internas antes das eleições gerais e com a participação dos filiados dos partidos (Estatuto de $\mathrm{PNH}$, artículo 90).

${ }^{41} \mathrm{O}$ texto dos novos estatutos assinala que: "O voto direto, igualitário e secreto de nossos militantes será o mecanismo por meio do qual [...] se escolherão os candidatos que a FMLN irá postular a cargos de eleição popular: Presidente e Vicepresidente da República [...] " (Estatutos FMLN, Titulo IV - Capítulo único das Eleições Internas, artigo 66). Segundo Lorena Peña, uma alta dirigente ortodoxa da Frente, essa mudança se deveu ao fato de que "não se pode pretender ser um país democrático com um partido autoritário [e ademais] a guerra já acabou, era preciso fazer o partido evoluir [...]" Declarações à autora em San Salvador, agosto de 2001.
} 
Antonio Cafiero e Carlos Menem em 1989); ${ }^{42}$ o PRD do México, ${ }^{43}$ a Esquerda Democrática do Equador; o PRD e o PRSC ${ }^{44}$ da República Dominicana; a Democracia Cristã (PDC) e o Partido Socialista ${ }^{45}$ do Chile e os partidos da Costa Rica.

Os dados mostram que um número importante de partidos incorpora este mecanismo para definir seus candidatos, mas as características dos procedimentos costumam apresentar variações. Embora tenham como traço comum o fato de que sejam os afiliados a escolher os candidatos, há casos em que essa decisão deve ser aprovada pelos órgãos colegiados, como nos partidos da Costa Rica, ${ }^{46}$ onde o PLN e o PUSC ${ }^{47}$ utilizaram os procedimentos estabelecidos na lei, ${ }^{48}$ tanto o da Convenção Nacional (internas), que se realiza com o padrão nacional, mas limitada pela obrigatoriedade de declarar-se simpatizante do partido para poder votar, como o da designação na Assembléia General. Assim, no caso da realização de eleições internas, é a Assembléia que deve ratificar esse resultado. No PRD da República Dominicana também instaurou-se em 1977 a realização de eleições internas fechadas para a escolha dos candidatos à Presidência da República, mas depois que as bases do partido elegem o candidato, o resultado deve ser proclamado pela Convenção Extraordinária reunida com essa finalidade. Uma modalidade distinta ocorre em outros partidos nos quais os órgãos nacionais são os que primeiro préqualificam os candidatos e depois convocam as bases do partido para que

\footnotetext{
${ }^{42}$ O PJ estabelece no artigo 26 do Capítulo VI de sua Carta Orgânica de 20 de setembro de 1991 que os candidatos a Presidente e Vice-presidente da Nação sejam escolhidos pelo voto direto dos afiliados e tomando toda a República como distrito único.

43 "Artigo $13^{\circ}$. A eleição dos candidatos (Aprovado no VI Congresso Nacional PRD) Zacatecas, 24-28 de abril de 2001 1.Poderão votar nas eleições internas de candidatas e candidatos do Partido os membros do mesmo com uma antigüidade de pelo menos seis meses na data da eleição [...]".

${ }^{44}$ A lei eleitoral estabelece que seja um órgão colegiado que deve designar o candidato (Tabela IV) e isso se mantém no Estatuto do PRSC, onde está dito que a Assembléia Nacional é que debe escolher os candidatos, mas na prática, se realizaram eleições internas fechadas para escolher o candidato a presidente. As primeiras se realizaram em 1996 e delas participaram cinco candidatos, entre os que se encontravam Ángel Lockuart, Víctor Gómez Bergés e Jacinto Peynado, o qual foi escolhido para as eleições do mesmo ano, na primeira vez em que Joaquín Balaguer não representou o partido.

45 “A seleção dos candidatos a cargos de representação popular se fará de forma democrática, pelo sistema de voto universal, secreto e informado em cada uma das instâncias que corresponda representar [...] O Conselho Regional poderá incorporar independentes. A seleção definitiva deverá considerar a discriminação positiva estabelecida para a mulher e a de jovens" (Art. 34, Estatutos Partidários do PS).

${ }^{46}$ O PLN realiza eleições internas desde 1952, enquanto que no caso do PUSC, há registros de que o partido utilizou o procedimento de Convenção Nacional em 1989 (Calderón Fournier contra Rodríguez Echeverría), e em 1993 (Rodríguez Echeverría contra Juan José Trejos Fonseca), mas em 1997 se utilizou a designação quando outros pré-candidatos desistiram de suas intenções (Fishman Zonzinski e Madríz de Mezerville).

${ }^{47} \mathrm{O}$ artigo 66 dos documentos partidários determina que a designação de candidatos do PUSC à Presidência e Vicepresidências da República é uma faculdade exclusiva da Assembléia Nacional. No caso do candidato à Presidência da República, a Assembléia Nacional exercerá esta faculdade ratificando o resultado obtido na correspondente Convenção Nacional. A Convenção Nacional é uma consulta eleitoral que se realiza com antecedência à designação, por parte da Assembléia Nacional. Nela, vários pré-candidatos submetem seus nomes ao julgamento de todos os cidadãos inscritos como eleitores no padrão elaborado pelo Tribunal Supremo de Eleições, que dêem previamente sua adesão formal e escrita ao Partido, para que estes - mediante votação universal, secreta e livre - definam quem será o candidato (art. 67).

${ }^{48}$ A lei eleitoral estabelece que os partidos, para designar seus candidatos, devem escolher entre dois mecanismos distintos: por nominação da Assembléia Nacional ou pelo método de internas, regulando a data em que a Convenção Nacional deve realizar-se e a duração das campanhas para esse processo interno.
} 
participem com seu voto do processo eleitoral, como no PLD da República Dominicana e no PDC do Chile, ${ }^{49}$ o que seria simplesmente um mecanismo de legitimação de acordos entre elites.

O uso de eleições internas fechadas pode ser também utilizado pela liderança como um mecanismo para dirimir conflitos dentro do partido, como foi o caso de Esquerda Democrática do Equador em $1987 .{ }^{50} \mathrm{O}$ partido procurou resolver a crise por meio de eleições internas e, momentaneamente, conseguiu que o enfrentamento se diluísse em torno da candidatura nacional, mas o movimento que gerou esse tipo de procedimento obrigou os dirigentes social-democratas a mudar o sistema por outros de corte mais centralizado, como a seleção dos candidatos mediante reuniões da Convenção Nacional que, na realidade funcionam por acordo prévio das elites partidárias. Finalmente, em alguns partidos se permite que as eleições internas não se realizem quando se apresenta um único candidato, situação que ocorreu no PRD do México em diversas oportunidades e onde se pode observar claramente o acordo entre as elites. ${ }^{51}$

\section{Órgãos colegiados internos (Convenções, Assembléias de Delegados)}

É um dos mecanismos mais usados historicamente entre os partidos políticos da América Latina, em particular quando se devem legitimar as decisões das elites partidárias; de um líder ou, simplesmente, quando se busca a participação dos membros delegados através de órgãos colegiados. Embora esse organismo costume ser uma instância de poder formal, muitas vezes tem capacidade suficiente para vetar as decisões de outros procedimentos, como se pôde observar no caso da FSLN da Nicarágua, com as trocas de candidatos depois da Consulta Popular de 1996, e nos processos de escolha da Costa Rica e do PRD da República Dominicana, que requerem a aprovação da Assembléia Nacional.

São muitos os partidos da América Latina que em seus Estatutos estabelecem que os candidatos sejam designados por um órgão colegiado. O PSC,

\footnotetext{
${ }^{49} \mathrm{O}$ Estatuto determina que os candidatos a cargos de representação popular sejam escolhidos por votação secreta, universal direta e informada de todos os militantes a quem corresponda votar, segundo o âmbito territorial e funcional do cargo a eleger, realizando desta maneira eleições internas fechadas, com pré-qualificação prévia dos candidatos. Desse modo, o processo supõe dois momentos. Primeiro, se realiza uma pré-qualificação dos postulantes para, em segundo lugar, submetêlos à votação universal, secreta e direta daqueles que gozem do direito de fazê-lo (Título IV, artigos 103 al 122).

${ }^{50}$ A luta interna pela candidatura foi entre Raúl Baca e Rodrigo Borja. O candidato Borja obteve 85 por cento dos votos e Baca, 12 por cento. Calculava-se que nesse momento o partido contava com cerca de 500.000 afiliados. Parece que, ao contabilizar os votos, o Tribunal Eleitoral Partidário inflou esses resultados, tendo em vista a imagem externa da agrupação. A disputa entre ambos candidatos esteve a ponto de provocar a divisão da organização, mas finalmente se realizou a eleição, na qual ganhou Borja e Baca se submeteu à disciplina do partido (Entrevistas 40 e 41, Freidenberg e Alcántara Sáez, 2001).

${ }^{51}$ Não se realizam eleições quando existe um candidato único. Nesse caso, é a Convenção que o designa. Portanto, contemplam-se tanto eleições internas como a designação através de órgãos colegiados. Na prática, as eleições internas não se realizaram devido à presença de seu líder e, até agora único candidato, Cauhtemoc Cárdenas.
} 
DP e ID no Equador; o PLC na Nicarágua; ${ }^{2}$ o PAN ${ }^{53}$ no México; o PAP no Peru; a ARENA em El Salvador; ${ }^{54}$ o PCC na Colômbia, como um mecanismo opcional às eleições internas; e os partidos da Guatemala e da República Dominicana, onde a Lei Eleitoral obriga que a Assembléia Nacional de cada partido realize a seleção dos candidatos. Nos partidos do Chile, os candidatos também são escolhidos por órgãos colegiados, como na RN e UDI, que selecionam uma postulação com a aprovação de dois terços do Conselho Geral que depois deve ser aprovada pelos militantes do partido; ou no PPD, em que o Conselho Geral tem a responsabilidade da escolha e proclamação do candidato.

Nos países que mudaram a legislação eleitoral no final da década de 1990, o procedimento mais comum até a reforma era o da designação pela Convenção Nacional e por isso consideramos relevante incluir na Tabela VIII os diferentes momentos partidários e seus respectivos procedimentos. O objetivo era mostrar que as mudanças ocorridas vão na direção de uma maior inclusão de atores no processo de seleção dos candidatos. Por exemplo, no Panamá, antes de haver eleições internas fechadas, os candidatos eram escolhidos por essa via. Até as eleições de 1999, em que não era obrigatória por lei a escolha de candidatos à Presidência e Vice-presidência da República mediante eleições internas, os candidatos eram designados pelo Diretório Nacional. ${ }^{55} \mathrm{O}$ mesmo ocorria na Bolívia, em Honduras e até no PJ da Argentina, a Convenção foi um espaço excepcional para legitimar a candidatura de Menem em 1995 e em 1999, com vistas a sua reeleição. Na União Cívica Radical, até que se realizaram as eleições internas abertas junto à FREPASO, era esse o mecanismo de escolha de seus candidatos, que supunha fortes lutas internas entre os postulantes.

A utilização de órgãos colegiados implica uma maior centralização no processo de tomada de decisões, mas também implica que os partidos são sujeitos de natureza autônoma, que não precisam de atores externos para definir suas

\footnotetext{
${ }^{52}$ No que se refere à escolha de candidatos a cargos de representação, de acordo com o estipulado no capítulo X, artigos 108 e 109 dos Estatutos do PLC; os sistemas, processos, mecanismos e procedimentos eleitorais, como plebiscitários, do partido devem refletir o espírito democrático que tem a organização, assim como sua igualdade, representatividade e transparência. No entanto, o partido não estabelece regras uniformes e precisas para a escolha de seus candidatos. Em realidade, o regulamento para os processos eleitorais do partido é variável e depende das resoluções que tome a Comissão Nacional Eleitoral e a Junta Diretiva Nacional do Partido e que depois consulte a Grande Convenção Nacional do partido. Ver Santiuste Cué (2001).

${ }^{53}$ Segundo os Estatutos, é a Convenção Nacional que realiza a seleção dos candidatos a presidente (Art. 38, frac. IV, Estatutos); depois das mudanças internas no PRI, diversas fuentes indicaram que o partido também se interessou por realizar eleições internas, mas na prática, isso não aconteceu.

${ }^{54} \mathrm{O}$ art. 108 do Estatuto proíbe expressamente o uso do voto secreto em qualquer dos organismos do partido e estabelece o uso da mão levantada, a designação nominal e a aclamação como únicos mecanismos de votação no marco de uma Convenção Nacional. Este foi (e é) um dos pontos de maior conflito entre os diferentes grupos do partido. A Liga de Areneros al Rescate, fundadores do partido, insistiu em sua incorporação para democratizar o partido, mas não conseguiram construir consensos para modificar os Estatutos partidários.

${ }^{55}$ Mireya Moscoso, presidenta do PA, se opôs energicamente à aprovação no primeiro debate da reforma eleitoral que estableceria o sistema de eleições internas, argumentando com o alto custo econômico desse tipo de processo e o potencial de divisões no interior dos partidos que elas pderiam acarretar (García Díez, 2001).
} 
candidaturas e, portanto, para tomar suas decisões. O fato de que muitos partidos continuem empregando esse tipo de mecanismo pode ser entendido como um elemento pouco democrático e de escassa transparência da vida interna das organizações partidárias mas, ao mesmo tempo, é preciso lembrar que, desde uma perspectiva da representação, esses órgãos são integrados por delegados democraticamente eleitos, o que legitima sua ação e desautoriza as acusações, nos casos em que funcionam conforme esses princípios. Esses órgãos contam inclusive com maiores garantias de representação territorial, o que permite a defesa das posições de diferentes regiões em um órgão de perfil nacional.

\section{Liderança do partido}

É bastante difícil encontrar em um texto partidário a declaração de que a escolha do candidato presidencial é realizada por uma única pessoa, como o líder de um partido. Formalmente, essa capacidade real do líder de influir na decisão final de quem vai ser candidato se encontra encoberta nos órgãos que funcionam como espaço de legitimação das decisões de um grupo pequeno de pessoas. Isso ocorre, por exemplo, naquelas organizações com lideranças de corte carismático, como o Partido Roldosista Equatoriano, no qual a Convenção Nacional é o órgão que ratifica a designação dos candidatos a cargos de representação popular e atua como um espaço de legitimação de propostas realizadas por outros, conforme seja a natureza do cargo a ocupar. Em termos formais, o Diretor Supremo, tal como os distintos Comandos (nacional, provincial ou cantonal), tem a possibilidade de sugerir os nomes dos candidatos a esse órgão de governo do partido, mas a incidência dos mesmos nos processos de seleção dos candidatos muda em função do cargo a eleger. No caso das candidaturas nacionais, é o próprio Diretor Supremo que define o nome do candidato, ao passo que em níveis menores, os caciques locais e os apóstolos do partido são os que influem significativamente na definição do aspirante. ${ }^{56}$ Outro exemplo nesse sentido é o do PRI do México, que desde 1929 utiliza como método de escolha de seus candidatos presidenciais o tradicional "dedazo", a partir do qual era o presidente da República em exercício que designava seu sucessor no cargo. No último processo eleitoral, o PRI mudou o costume do "dedazo" e realizou eleições internas, como uma tentativa de legitimar seu processo interno, mas, especialmente, pela vontade de seus dirigentes, que decidiram utilizar esse mecanismo; finalmente, em 2001, os Estatutos do partido foram modificados, incorporando a realização de eleições internas, que se realizaram em fevereiro de 2002, resultando na vitória de Roberto Madrazo. Até então, os Estatutos eram flexíveis com respeito aos tipos de mecanismos que se podiam empregar para escolher os candidatos.

\footnotetext{
${ }^{56}$ Ver Freidenberg (2001).
} 
TABELA VII

Seleção dos candidatos presidenciais na América Latina (ano de realização)

\begin{tabular}{|c|c|c|c|c|c|c|}
\hline & $\begin{array}{c}\text { Eleitorado } \\
\text { (internas abertas) }\end{array}$ & $\begin{array}{c}\text { Membros dos } \\
\text { partidos (internas } \\
\text { fechadas) }\end{array}$ & $\begin{array}{c}\text { Órgãos } \\
\text { colegiados }\end{array}$ & $\begin{array}{c}\text { Órgãos } \\
\text { nacionais } \\
\text { propõem e } \\
\text { depois há } \\
\text { eleições } \\
\text { internas }\end{array}$ & $\begin{array}{c}\text { Órgãos } \\
\text { nacionais } \\
\text { ratificam } \\
\text { resultados } \\
\text { de eleições } \\
\text { internas }\end{array}$ & $\begin{array}{l}\text { Líder } \\
\text { do } \\
\text { partido }\end{array}$ \\
\hline Argentina & $\begin{array}{c}\text { FREPASO (94) } \\
\text { FREPASO-UCR } \\
(99)\end{array}$ & PJ $(88)^{a}$ & $\begin{array}{c}\text { PJ } \\
(83,94,99)^{a} \\
\text { UCR } \\
(83,88,94)\end{array}$ & & & \\
\hline Bolívia & $\begin{array}{l}\text { MNR (99), } \\
\text { MIR (99) }\end{array}$ & & $\begin{array}{c}\operatorname{UCS}^{\mathrm{b}}, \\
\mathrm{MNR}^{\mathrm{b}} \\
\mathrm{MIR}^{\mathrm{b}}, \mathrm{ADN}^{\mathrm{b}}\end{array}$ & & & \\
\hline Colômbia & $\operatorname{PLC}(90,94)^{a}$ & PCC (98) & $\begin{array}{l}\text { PCC, PLC } \\
(98)^{a}\end{array}$ & & & \\
\hline Costa Rica & & & $\begin{array}{l}\text { PFD, PLN, } \\
\text { PUSC }^{a}\end{array}$ & & $\begin{array}{l}\text { PFD, PLN, } \\
\text { PUSC }^{a}\end{array}$ & \\
\hline Chile & $\begin{array}{c}\text { Concertación } \\
(93,99,2001)\end{array}$ & PS & PPD & PDC, RN, UDI & & \\
\hline Equador & & ID (84) & $\begin{array}{l}\text { PSC, DP, } \\
\text { ID, PRE }\end{array}$ & & & PRE \\
\hline El Salvador & & FMLN (99) & ARENA & & & \\
\hline Guatemala & & & FRG, PAN & & & \\
\hline Honduras & & $\begin{array}{l}\text { PLH, PNH } \\
(89 \text { a } 2001)\end{array}$ & & & & \\
\hline México & PRI (99) & PRD, PRI (2002) & $\begin{array}{c}\text { PAN, PRD, } \\
\text { PRI }\end{array}$ & & & $\begin{array}{c}\text { PRI } \\
\text { (até } \\
1999)\end{array}$ \\
\hline Nicarágua & & & $\begin{array}{c}\text { PLC } \\
(96,2001)\end{array}$ & & $\begin{array}{c}\text { FSLN } \\
(96,2001)\end{array}$ & PLC \\
\hline Panamá & & $\begin{array}{c}\text { PA (98), PRD } \\
(98)\end{array}$ & $\mathrm{PA}^{\mathrm{b}}, \mathrm{PRD}^{\mathrm{b}}$ & & & \\
\hline Paraguai & & ANR-PC, PLRA & & & & \\
\hline Peru & & & PAP & & & \\
\hline $\begin{array}{c}\text { República } \\
\text { Dominicana }\end{array}$ & & $\begin{array}{l}\text { PRD (d77), } \\
\text { PRSC (96) }\end{array}$ & $\mathrm{PRSC}^{\mathrm{b}}$ & $\mathrm{PLD}^{\mathrm{C}}$ & & \\
\hline Uruguai & $\begin{array}{l}\text { EP.FA (99), PC } \\
(99), \text { PN (99)* }\end{array}$ & & & & & \\
\hline
\end{tabular}

* Antes da reforma eleitoral, os candidatos eram escolhidos pelo sistema de lei de inscrições, depois do acordo entre as elites para as designações.

a Indica que há mais de um ator que participa no processo de seleção de candidatos.

${ }^{b}$ Assinala que esse mecanismo foi utilizado até que se realizou uma reforma eleitoral no sistema e, com isso, modificaram-se as normas de eleição.

c. Os órgãos nacionais pré qualificam as candidaturas e depois elas concorrem entre si.

Fonte: Elaboração própria. 


\section{Conclusões}

Uma série de perguntas vinculadas às características dos processos de seleção de candidatos serviu de guia para este trabalho. Estávamos interessados em observar o modo como os partidos políticos da América Latina escolhem seus candidatos a presidente da República e examinar a natureza desses processos. 0 objetivo central era construir um mapa que permitisse ordenar os tipos de mecanismos que são utilizados e que ajudasse a discutir sua capacidade de inclusão em termos da democratização interna.

A primeira questão que buscamos responder estava relacionada com quem pode ser candidato nos partidos da região. Embora as regras eleitorais nacionais estabeleçam formalmente que todos os cidadãos podem se apresentar como candidatos; na prática, essas regras exigem uma série de requisitos que são obrigatórios para todos os partidos e que são excludentes de cada um dos cargos em disputa. Esses requisitos de caráter sistêmico, por seu turno, complementam-se com outros condicionamentos formais estipulados pelos próprios partidos. Ou seja, existem restrições externas e internas em relação às candidaturas. 0 padrão geral mostra que, na maioria dos casos, os partidos não têm requisitos formais muito exigentes para os aspirantes a uma candidatura; muitos deles exigem que sejam filiados ao partido e uns poucos indicam que, além disso, devem cumprir outra série de atributos, entre os quais se destacam a antigüidade de afiliação (isto é, que o candidato potencial tenha sido durante um determinado período membro do partido) ou o pagamento das cotas em dia. Ainda assim, é normalmente fácil para os partidos acomodar suas regras em função de suas estratégias eleitorais, possibilitando que os órgãos do partido legitimem através de mecanismos excepcionais uma candidatura que não cumpre com todos os requisitos exigidos.

Nesse sentido, interessa-nos destacar o fato de que os requisitos excepcionais podem ser pensados como um incentivo contra os trânsfugas ou as trocas de partidos, nos sistemas de institucionalização fraca, ${ }^{57}$ nos quais não costuma haver laços fortes entre os membros do partido e a organização. Por exemplo: o fato de um partido não aceitar como candidato uma pessoa que teve uma participação destacada em uma agrupação antagônica pode desestimular o abandono do partido e, em âmbitos institucionais menores como o Legislativo, pode funcionar como um estímulo para manter a disciplina partidária. Desse modo, é importante pensar na maneira como se podem fortalecer as exigências internas que as organizações partidárias fazem como um modo de reforçar a capacidade para controlar as trocas de partidos. Mas, isso adquire maior relevância em âmbitos locais ou intermediários do que em nacionais, onde normalmente o candidato presidencial costuma ser um dos líderes partidários que controla a agrupação.

\footnotetext{
${ }^{57}$ Ver Mainwaring e Scully (1995).
} 
A segunda pergunta que nos interessava responder era sobre quem escolhe os candidatos partidários. Na América Latina é possível encontrar diferenças em função da vigência (ou não) de uma lei eleitoral que obrigue os partidos a utilizar uma maneira determinada para escolher seus candidatos. A discussão subjacente a essa questão tem a ver com a relação entre as organizações partidárias e seu ambiente e, nesse sentido, os dados apresentados são um indicador de como o entorno pode modificar o comportamento dos atores intrapartidários. As reformas eleitorais realizadas nas últimas décadas apontam para um incremento do controle externo dos partidos, no sentido de uma maior transparência dos procedimentos internos e de uma maior democratização; por outro lado, a imposição de mecanismos desde fora dos partidos vai contra a autonomia organizativa partidária. Nesse sentido, basta recordar que na maioria dos casos em que houve reforma instaurou-se um mecanismo mais participativo de seleção de candidatos que procura uma maior inclusão de atores mediante eleições, seja na direção de todo o eleitorado, seja em relação aos membros do partido, o que demonstra o tipo de vontade política que está por trás das reformas.

A terceira pergunta tinha a ver com o âmbito territorial em que se desenvolvem os processos. A análise mostrou que, no caso das candidaturas a presidente da República, são os órgãos nacionais que detêm a iniciativa. Não se pôde constatar a vigência na região de um processo de seleção de uma candidatura nacional que fosse descentralizado e que supusesse a participação ativa das instâncias locais, mas este é um tema que deve ser ainda aprofundado pelas implicações que as relações territoriais têm sobre os diferentes âmbitos do comportamento partidário. Mesmo assim, os âmbitos nacionais continuam sendo os que impõem as candidaturas nacionais na maioria dos casos analisados. E isso se vincula à questão seguinte, sobre quem decide o postulante à Presidência da República.

Com respeito aos mecanismos que se utilizam para designar os candidatos, encontramos que apesar da tendência vigente na região de uma maior abertura a diferentes atores, com a realização de eleições, tanto abertas como fechadas, ainda é muito importante o papel desempenhado pelos órgãos colegiados dos partidos, uma vez que são os espaços de legitimação das elites partidárias. Isso aparece com mais força se levarmos em conta que há partidos que consideram válidos mais de um mecanismo de eleição, utilizando o que mais convém às estratégias eleitorais da coalizão dominante ou do próprio partido. De um lado, isso mostra uma forte centralização do processo de tomada de decisões dos partidos e alerta sobre os desafios pendentes com relação a uma maior descentralização desse processo e uma maior transparência em busca de níveis mais efetivos de democratização interna, entendendo-se esta no sentido de uma maior inclusão de atores nesse processo de tomada de decisões e, em particular, quando o funcionamento desses 
órgãos está longe de responder a mecanismos de deliberação de natureza democrática. Mas também, por outro lado, o fato de que sejam os órgãos colegiados a tomar a decisão de escolher um candidato pode ser visto de outra maneira. Trata-se do órgão que integra territorialmente os diversos âmbitos da organização partidária e, como tal, é o que teoricamente garante a representação igualitária dos membros do partido. Sua composição é fixada em função de diversos critérios, principalmente levando em conta o peso eleitoral do distrito e seu tamanho em número de militantes. Assim, esse mecanismo de eleição de candidatos pode significar uma participação mais eqüitativa dos membros do partido em termos territoriais.

Por fim, é preciso destacar que nos últimos anos houve tentativas importantes para que os partidos da região incorporassem mais atores no processo de definição das candidaturas, processos, em muitos casos, exitosos. Mesmo assim, apesar de que a tendência vai na direção da mudança dos métodos de seleção de candidatos, é cedo para inferir efeitos que permitam sustentar conclusões gerais, seja com relação à representação política, à participação ou à democratização interna. Em futuras pesquisas, continuaremos analisando os efeitos dessa relação, assim como também os processos de seleção de candidatos em outros níveis institucionais, como o Legislativo, onde esses mecanismos apresentam características particulares, pois levam em consideração outras variáveis externas e internas ao partido que afetam o processo de decisão.

\section{BIBLIOGRAFIA}

AJENJO FRESNO, Natalia. (2001) Honduras. In: ALCÁNTARA SÁEZ, Manuel \& FREIDENBERG, Flavia, (eds.) Partidos políticos de América Latina. Salamanca, Ediciones Universidad de Salamanca.

AJENJO FRESNO, Natalia \& GARCÍA DÍEZ, Fátima. (2001) Guatemala In: ALCÁNTARA SÁEZ, Manuel \& FREIDENBERG, Flavia, (eds.) Partidos políticos de América Latina. Salamanca, Ediciones Universidad de Salamanca.

ALCÁNTARA SÁEZ, Manuel. (2001) Experimentos de democracia interna. Las primarias de partidos en América Latina. Documentos de Trabajo Doctorado en Ciencia Política (6). México, FLACSO.

ALCÁNTARA SÁEZ, Manuel \& FREIDENBERG, Flavia, (eds.) (2001) Partidos políticos de América Latina. Salamanca, Ediciones Universidad de Salamanca.

ALFARO SALAS, Sergio. (2001) Sistema electoral y cambio organizativo en los partidos: el caso de Costa Rica. América Latina Hoy, 27 (abril):67-87. (Salamanca, Ediciones Universidad de Salamanca).

BILLIE, Lars. (2001) Democratizing a Democratic procedure: myth or reality? Candidate Selection in Western European Parties, 1960-1990. Party Politics, Londres 7(3):363-380.

BUQUET, Daniel. (2001) Selección de candidatos y fraccionalización partidaria en Uruguay (19421999). Trabalho apresentado no XXIII International Meeting of Latin American Studies Association. Washington, 6-8 de setembro. 
CAREY, John \& SHUGART, Matthew. (1995) Incentives to Cultivate a Personal Vote: A Rank Ordering of Electoral Formulas. Electoral Studies, Austin, Oxford e Essex 14(4):417-439. .

COPPEDGE, Michael. (1994) Strong Parties and Lame Ducks. Presidential Partyarchy and Factionalism in Venezuela. Stanford, Stanford University Press.

DE LUCA, Miguel; JONES, Mark \& TULA, María Inés. (2000) Partidos políticos y selección de candidatos en Argentina (1983-1999). Trabalho apresentado no XXII International Meeting of Latin American Studies Association. Miami, 16-18 de março.

DIAZ, Christopher. (2000) Effects of Party Competition on the Quality of PRI Candidates: An Analysis of Mexican Gubernatorial Elections: 1989-1999. Trabalho apresentado no XXIV Encontro Anual Internacional da Asociación de Estudios Latinoamericanos, Miami (Florida), 16-18 de março.

DOWNS, Anthony. (1992) Teoría económica de la acción política. In: BATTLE, Albert. (ed.) Diez Textos Básicos de Ciencia Política. Barcelona, Ariel Ciencia Política.

DUVERGER, Maurice. (1951) Les partis politiques. Paris, Librairie Armand Colin.

FREIDENBERG, Flavia. (2001) El reino de Abdalá Bucaram: El Partido Roldosista Ecuatoriano en busca del poder (1982-2000). Salamanca, Tese de doutorado, Ediciones Universidad de Salamanca..

FREIDENBERG, Flavia \& ALCÁNTARA SÁEZ, Manuel. (2001) Los dueños del poder: Partidos políticos en Ecuador (1978-2000). Quito, Flacso - Sede Ecuador.

EPSTEIN, Leon. 2000 (1967) Political Parties in Western Democracies. Nova York, Washington e Londres, Praeger.

GALLAGHER, Michael. (1988a) Introduction. In: GALLAGHER, Michael \& MARSH, Michael. (eds.). Candidate Selection in Comparative Perspective: The Secret Garden of Politics. Londres, Sage.

(1988b) Conclusion. In: GALLAGHER, Michael \& MARSH, Michael. (eds.). Candidate Selection in Comparative Perspective: The Secret Garden of Politics. Londres, Sage.

GARCÍA DÍEZ, Fátima. (2001) Panamá. In: ALCÁNTARA SÁEZ, Manuel \& FREIDENBERG, Flavia, (eds.) Partidos políticos de América Latina. Salamanca, Ediciones Universidad de Salamanca.

GARCÍA MONTERO, Mercedes. (2001) Bolivia. In: ALCÁNTARA SÁEZ, Manuel \& FREIDENBERG, Flavia, (eds.) Partidos políticos de América Latina. Salamanca, Ediciones Universidad de Salamanca.

JANDA, Kenneth. (1980) Political Parties: A Cross-National Survey. Nova York, The Free Press.

JIMENEZ BADILLO, Margarita. (2001) Partido Acción Nacional. In: ALCÁNTARA SÁEZ, Manuel \& FREIDENBERG, Flavia, (eds.) Partidos políticos de América Latina. Salamanca, Ediciones Universidad de Salamanca.

KATZ, Richard. (2001) The problem of candidate selection and models of party democracy. Party Politics, Londres, 7(3):277-296.

University Press

(1980) A Theory of Parties and Electoral Systems. Baltimore, The Johns Hopkins

KATZ, Richard \& MAIR, Peter. (1990) Three Faces of Party Organization: Adaptation and Change. Trabalho preparado para o XII Congresso Mundial de Sociologia, Madri, 9-13 de julho.

KIRCHHEIMER, Otto. 1980 (1965). Derwander des westeuropäischen parteisystems. In: Politishe Wiertel Jahresschrift, VV-24-41 (Tradução espanhola consultada: KIRCHHEIMER, Otto. EI camino hacia el partido de todo el mundo, In: LENK, Kurt \& NEUMANN, Franz, eds. Teoría y sociología críticas de los partidos políticos. Barcelona, Editorial Anagrama, pp. 328-347). 
MAINWARING, Scott \& SCULLY, Timothy. (1995) Building Democratic Institutions. Stanford, Stanford University Press.

MAINWARING, Scott \& SHUGART, Matthew S. (1998) Presidencialismo y sistema de partidos en América Latina. Posdata, Buenos Aires, 3/4: 133-181 (agosto)

MARENGHI, Patricia. (2001) Organización de los partidos políticos. Dimensiones Comparadas. In: ALCÁNTARA SÁEZ, Manuel \& FREIDENBERG, Flavia, (eds.) Partidos políticos de América Latina. Salamanca, Ediciones Universidad de Salamanca.

MARTÍNEZ BARAHONA, Elena. (2001) Uruguay. In: ALCÁNTARA SÁEZ, Manuel \& FREIDENBERG, Flavia, (eds.) Partidos políticos de América Latina. Salamanca, Ediciones Universidad de Salamanca.

MARTZ, John. (1999) Political Parties and Candidate Selection in Venezuela and Colombia. Political Science Quaterly, Nova York, 114 (4):639-659.

PANEBIANCO, Angelo. (1982) Modelli di partito. Bologna: Societa Editrice il Mulino. (Edição espanhola consultada: Modelos de partido. Madri: Alianza Editorial, 1990).

PICAZO, Ines. (2001) Chile. In: ALCÁNTARA SÁEZ, Manuel \& FREIDENBERG, Flavia, (eds.) Partidos políticos de América Latina. Salamanca, Ediciones Universidad de Salamanca.

RAHAT, Gideon \& HAZAN, Reuven. (2001) Candidate Selection Methods: An analytical framework. Party Politics , Londres, 7(3):297-322.

ROLL, David. (2001) Colombia. In: ALCÁNTARA SÁEZ, Manuel \& FREIDENBERG, Flavia, (eds.) Partidos políticos de América Latina. Salamanca, Ediciones Universidad de Salamanca.

SANTIUSTE CUÉ, Salvador. (2001) Nicaragua. In: ALCÁNTARA SÁEZ, Manuel \& FREIDENBERG, Flavia, (eds.) Partidos políticos de América Latina. Salamanca, Ediciones Universidad de Salamanca.

SARTORI, Giovanni. (1992) Partidos y Sistemas de partidos. Madri, Alianza Editorial. Segunda edição ampliada.

SCHATTSCHNEIDER, Elmer E. (1941) Party Government. Nova York, Holt, Rinehart and Winston.

SCHLESINGER, Joseph. (1994) Political Parties and the Winning of Office. Ann Arbor, The University of Michigan Press.

SCHUMPETER, Joseph. (1962) Capitalism, Socialism and Democracy. Nova York, Harper and Row.

SIAVELIS, Peter. (2001) The hidden logic of candidate selection for Chilean Parliamentary elections. Trabalho apresentado no XXIII International Meeting of Latin American Studies Association. Washington, 6-8 de setembro.

(1997) Candidate Selection Strategies for Chilean Parliamentary. Trabalho apresentado no XX Encontro Anual Internacional da Asociación de Estudios Latinoamericanos, Guadalajara (México), 17-19 de abril.

TAYLOR, Steven. (2000) Towards a Detailed Discussion of Candidate Selection in Latin America. Trabalho apresentado no XXII Encontro Internacional da Asociación de Estudios Latinoamericanos, Miami, Florida, 16 e 18 de março.

TAYLOR-ROBINSON, Michelle. (2001) Candidate Selection in Costa Rica. Trabalho apresentado no XXIII International Meeting of Latin American Studies Association. Washington, 6-8 de setembro.

VALDÉS, Leonardo. (2001) La selección de candidatos y el cambio de sistema de partidos políticos en México. Trabalho apresentado no XXIII International Meeting of Latin American Studies Association. Washington, 6-8 de setembro. 
VON BEYME, Klaus. (1986) Los partidos politicos en las democracias occidentales. Madrid, Centro de Investigaciones Sociológicas.

WARE, Alan. (1996). Political Parties and Party Systems. Nova York, Oxford University Press.

WEBER, Max. (1992) Economía y Sociedad. México, Fondo de Cultura Económica,.

ANEXO I

Requisitos para ser candidato a Presidente da República segundo a norma eleitoral

0 que estabelece a norma?

\begin{tabular}{|c|c|}
\hline País & Candidato presidencial \\
\hline Argentina & $\begin{array}{l}\text { Se requer ter nascido no território argentino, ou ser filho de cidadão nativo, tendo } \\
\text { nascido en país estrangeiro, e as demais qualidades exigidas para ser eleito senador } \\
\text { (Artigo } 89, \mathrm{CN} \text { ). }\end{array}$ \\
\hline Bolívia & $\begin{array}{l}\text { Exige-se ser boliviano de origem e ter cumprido os deveres militares se corresponde; ter } 35 \\
\text { anos completos; estar inscrito no Registro Eleitoral; ser postulado por um partido político } \\
\text { ou por agrupações cívicas representativas das forças vivas do país com personalidade } \\
\text { jurídica reconhecida, formando blocos ou frentes com os partidos políticos. Não ter sido } \\
\text { condenado à pena corporal, salvo reabilitação concedida pelo Senado; nem ter abandono } \\
\text { de cargo ou auto de culpa executados; não estar compreendido nos casos de exclusão e de } \\
\text { incompatibilidade previstos por Lei (Artigo } 104 \text {, Lei de } 25 \text { de junho de } 1999, n^{\circ} 1984 \text { ). }\end{array}$ \\
\hline Colômbia & $\begin{array}{l}\text { Ser colombiano de nascimento, cidadão em exercício e maior de trinta anos (Artigo 191, } \\
\text { CN). }\end{array}$ \\
\hline Costa Rica & $\begin{array}{l}\text { Ser costarriquenho de nascimento e cidadão em exercício; ser do estado secular; ser } \\
\text { maior de trinta anos (Artigo } 131, \mathrm{CN} \text { ). }\end{array}$ \\
\hline Chile & $\begin{array}{l}\text { Ter nascido no território do Chile, ter completo quarenta anos de idade e possuir as } \\
\text { demais qualidades necessárias para ser cidadão con direito a sufrágio (Artigo } 25, \mathrm{CN} \text { ). } \\
\text { As declarações de candidaturas de partidos políticos a Presidente da República deverão } \\
\text { cumprir com os seguintes requisitos especiais: Somente poderão ser declaradas pelos } \\
\text { partidos constituídos em todas as regiões do país, e aqueles partidos que não estejam } \\
\text { constituídos em todas as regiões do país poderão efetuar estas declarações } \\
\text { apresentando uma quantidade total de filiados nas regiões em que se encontram } \\
\text { legalmente constituídos não inferior ao 0,5 por cento estabelecido no artigo anterior (Art. } \\
\text { 14, Lei Orgânica Constitucional sobre Votações Populares e Escrutínios, 1988). }\end{array}$ \\
\hline Equador & $\begin{array}{l}\text { Entre } 1978 \text { e 1998, não podiam apresentar-se como candidatos os parentes diretos do } \\
\text { Presidente em exercício, os ex-presidentes e ex-vice-presidentes, os ministros religiosos } \\
\text { de qualquer culto, os membros das Forças Armadas, a Polícia e a burocracia estatal, os } \\
\text { representantes legais de companhias estrangeiras e aqueles que tiveram contrato com o } \\
\text { Estado. Os candidatos deviam cumprir com o requisito da idade ( } 35 \text { anos) e o de filiação } \\
\text { e patrocínio a uma organização partidária. Ver Lei de Eleições (1978, art. 47). Para } \\
1998, \text { modificaram-se os requisitos no texto constitucional. Os candidatos a presidente e } \\
\text { vice-presidente devem cumprir os requisitos de nacionalidade e de idade (40 anos no } \\
\text { mínimo), podem ser reeleitos sempre que conste um mandato intermediário e não } \\
\text { precisam estar filiados a partidos políticos para poder participar das eleições. }\end{array}$ \\
\hline El Salvador & $\begin{array}{l}\text { Ser salvadorenho de nascimento, filho de pai o mãe salvadorenha; de estado secular, } \\
\text { maior de trinta anos de idade, de moralidade e instrução notórias; estar no exercício dos } \\
\text { direitos de cidadão, tê-lo estado nos seis anos anteriores à eleição e estar afiliado a um } \\
\text { dos partidos políticos reconhecidos legalmente (art.151, CN). }\end{array}$ \\
\hline
\end{tabular}




\begin{tabular}{|c|c|}
\hline Guatemala & $\begin{array}{l}\text { Ser guatemalteco de origem, cidadão em exercício e maior de quarenta anos (art. 185, } \\
\mathrm{CN} \text { ). }\end{array}$ \\
\hline Honduras & $\begin{array}{l}\text { Ser hondurenho de nascimento; maior de trinta anos; estar no gozo dos direitos do } \\
\text { cidadão e ser do estado secular (art } 238, \mathrm{CN} \text { ). }\end{array}$ \\
\hline México & $\begin{array}{l}\text { Ser cidadão mexicano por nascimento, em pleno gozo de seus direitos, filho de pai ou } \\
\text { mãe mexicanos e ter residido no país ao menos durante vinte anos; ter } 35 \text { anos } \\
\text { completos na época da eleição; ter residido no país durante todo o ano anterior aol dia } \\
\text { da eleição. A ausência do país até trinta dias não interrompe a residência; não pertencer } \\
\text { a estado eclesiástico nem ser ministro de algum culto; não estar em serviço ativo, no } \\
\text { caso de pertencer ao exército, seis meses antes do dia da eleição; não ser secretário ou } \\
\text { subsecretário de estado, chefe ou secretário geral de departamento administrativo, } \\
\text { procurador geral da República, nem governador de algum estado, a menos que deixe o } \\
\text { cargo seis meses antes do dia da eleição, e não estar compreEndido em alguMa das } \\
\text { causas de incapacidade estabelecidas no Artigo } 83 \text { (Artigo 82, CN). }\end{array}$ \\
\hline Nicarágua & $\begin{array}{l}\text { Ser natural da Nicarágua; estar em pleno gozo de seus direitos civis e políticos; ter } \\
\text { cumprido } 25 \text { anos de idade; ter residido ou trabalhado de forma contínua no país nos } \\
\text { cinco anos anteriores à eleição, exceto se estivesse cumprindo missão diplomática ou } \\
\text { estudos no exterior. }\end{array}$ \\
\hline Paraguai & $\begin{array}{l}\text { Ter nacionalidade paraguaia natural; ter completado trinta e cinco anos, e estar em } \\
\text { pleno exercício de seus direitos civis e políticos (artigo 228. Dos requisitos, CN). }\end{array}$ \\
\hline Panamá & $\begin{array}{l}\text { Ser panamenho por nascimento e ter completado trinta e cinco anos de idade (artigo } \\
174, \mathrm{CN} \text { ). }\end{array}$ \\
\hline Peru & $\begin{array}{l}\text { Ser peruano de nascimento, ter mais de trinta e cinco anos de idade no momento da } \\
\text { postulação e gozar do direito de sufrágio (Artigo } 110, \mathrm{CN} \text { ). }\end{array}$ \\
\hline \begin{tabular}{l|} 
República \\
Dominicana
\end{tabular} & $\begin{array}{l}\text { Ser dominicano de nascimento ou origem. Ter completado } 30 \text { anos de idade. Estar em } \\
\text { pleno exercício dos direitos civis e políticos. Não estar em serviço militar ou policial } \\
\text { ativo, pelo menos durante o ano que preceda a eleição (Artigo } 50, \mathrm{CN} \text { ). }\end{array}$ \\
\hline Venezuela & $\begin{array}{l}\text { Ser venezuelano ou venezuelana por nascimento, não possuir outra nacionalidade, maior } \\
\text { de trinta anos, de estado secular e não estar submetido o submetida a condenação } \\
\text { mediante sentença definitivamente firme e cumprir com os demais requisitos } \\
\text { estabelecidos nesta Constituição (Artigo } 227, \mathrm{CN} \text { ). }\end{array}$ \\
\hline Uruguai & $\begin{array}{l}\text { Somente poderão ser eleitos os cidadãos naturais em exercício, que tenham trinta e } \\
\text { cinco anos completos de idade (Artigo } 151, \mathrm{CN} \text { ). }\end{array}$ \\
\hline
\end{tabular}

Fonte: Textos Constitucionais e Base de Dados Política das Américas (http://www.georgetown.edu/pdba/) 
ANEXO II

Requisitos para ser candidato a Presidente da República conforme o partido

0 que estabelecem as regras partidárias?

\begin{tabular}{|c|c|c|}
\hline País & \multicolumn{2}{|c|}{ Candidato presidencial } \\
\hline \multirow{3}{*}{ Argentina } & PJ & Ser afiliado. Também se apresentam candidatos externos (patrocinados). \\
\hline & UCR & $\begin{array}{l}\text { Estar incluído nos registros partidários e ter uma antigüidade mínima e } \\
\text { contínua de cinco anos devendo reunir também os requisitos exigidos pela } \\
\text { Constituição Nacional (Carta Orgânica, artigo 14). }\end{array}$ \\
\hline & FREPASO & Ser afiliado. Também se apresentam candidatos externos (patrocinados). \\
\hline \multirow{4}{*}{ Bolívia } & MNR & $\begin{array}{l}\text { Pelo menos um dos dois membros da fórmula presidencial deve ser } \\
\text { membro do partido. Também se apresentam candidatos externos } \\
\text { (patrocinados). }\end{array}$ \\
\hline & UCS & - \\
\hline & ADN & . \\
\hline & MIR & - \\
\hline \multirow[b]{2}{*}{ Colômbia } & PL & Ser afiliado. \\
\hline & $\mathrm{PC}$ & Ser afiliado. \\
\hline \multirow[b]{2}{*}{ Costa Rica } & PLN & Ser afiliado. \\
\hline & PUSC & $\begin{array}{l}\text { Estabelece-se o requisito de militância que sustenta que para ser } \\
\text { postulado em nome del Partido a qualquer dos cargos de eleição popular } \\
\text { - além de todos os outros requisitos que estabeleçam la lei e estes } \\
\text { Estatutos, é condição indispensável ser militante do Partido, com uma } \\
\text { militância contínua e claramente verificável de, pelo menos, quatro anos } \\
\text { imediatamente anteriores à postulação, exceto aqueles casos em que } \\
\text { estes Estatutos estabeleçam uma condição diferente. Estatutos do PUSC, } \\
\text { art. } 64 \text {. }\end{array}$ \\
\hline \multirow{5}{*}{ Chile } & RN & Ser afiliado. \\
\hline & UDI & Ser afiliado. \\
\hline & PPD & Ser afiliado. \\
\hline & PDC & $\begin{array}{l}\text { Ser afiliado. Para postular a um cargo nacional do partido, os Estatutos } \\
\text { exigem seis anos de militância (art. 110). }\end{array}$ \\
\hline & PS & Ser afiliado. Permite-se a inclusão de independentes. \\
\hline \multirow{5}{*}{ Equador } & PSC & Ser afiliado. Aceitam afiliados, independentes e patrocinados desde 1996. \\
\hline & PRE & Ser afiliado. Aceitam afiliados, independentes e patrocinados desde 1996. \\
\hline & ID & Ser afiliado. Aceitam afiliados, independentes e patrocinados desde 1996. \\
\hline & DP & Ser afiliado. Aceitam afiliados, independentes e patrocinados desde 1996. \\
\hline & MUPP & $\begin{array}{l}\text { Não há regulamento. Mas podem ser candidaturas independentes, } \\
\text { promovidas por organizações sociais ou grupos de base. }\end{array}$ \\
\hline \multirow{2}{*}{ El Salvador } & ARENA & Ser afiliado. \\
\hline & FMLN & Ser afiliado. Não menciona expressamente no Estatuto outro requisito. \\
\hline \multirow{2}{*}{ Guatemala } & FRG & Ser afiliado. \\
\hline & PAN & Ser afiliado. Não estabelece expressamente no Estatuto outro requisito. \\
\hline
\end{tabular}

(continua) 
Como se escolhe um candidato a Presidente?

(continuação do ANEXO II)

\begin{tabular}{|c|c|c|}
\hline \multirow{2}{*}{ Honduras } & $\mathrm{PNH}$ & Ser afiliado. \\
\hline & PLH & Ser afiliado. \\
\hline \multirow{3}{*}{ México } & PAN & Ser afiliado. \\
\hline & PRI & $\begin{array}{l}\text { Ser cidadão mexicano por nascimento e em pleno gozo de seus direitos } \\
\text { políticos; satisfazer os requisitos exigidos pelos regulamentos eleitorais } \\
\text { aplicáveis às eleições constitucionais de que se trate; ser militante e ter } \\
\text { mostrado lealdade pública para com a Declaração de Princípios e o } \\
\text { Programa de Ação, assim como observância estrita dos Estatutos do } \\
\text { Partido; comprovar a qualidade de Quadro em atividades partidárias; não } \\
\text { ter sido dirigente, candidato nem militante destacado de partidos } \\
\text { antagônicos ao PRI; estar em dia no pagamento de suas cotas; cumprir o } \\
\text { Código de Ética Partidária; mostrar uma conduta pública adequada e não } \\
\text { ter sido sentenciado por delito intencional da ordem comum ou no } \\
\text { desempenho das funções públicas; apresentar um programa de trabalho } \\
\text { perante o Conselho Político. Para os casos de Presidente da República e } \\
\text { Governador, se exigirá comprovar a qualidade de Quadro, Dirigente e } \\
\text { haver tido um posto de eleição popular através do Partido, assim como } \\
\text { dez anos de militância partidária. (Estatuto do PRI, art. 144). }\end{array}$ \\
\hline & PRD & $\begin{array}{l}\text { Ser afiliado e ter as cotas pagas em dia. Também se apresentam } \\
\text { candidatos externos (patrocinados). }\end{array}$ \\
\hline \multirow{2}{*}{ Nicarágua } & FSLN & Ser afiliado. \\
\hline & PLC & Ser afiliado. \\
\hline \multirow[b]{2}{*}{ Paraguai } & PLRA & Ser afiliado. Não contempla outro requisito nos Estatutos. \\
\hline & ANR-PC & $\begin{array}{l}\text { Antigüidade na filiação de entre } 3,5 \text { ou } 10 \text { anos, em função do cargo em } \\
\text { questão. Os filiados que se apresentem como candidatos à Presidência e } \\
\text { Vice-presidência da República nas eleições internas deverão contar con } \\
\text { um mínimo de dez anos. }\end{array}$ \\
\hline \multirow[b]{2}{*}{ Panamá } & PA & Ser afiliado. \\
\hline & PRD & Ser afiliado. \\
\hline Peru & PAP & Ser afiliado. \\
\hline \multirow{3}{*}{$\begin{array}{l}\text { República } \\
\text { Dominicana }\end{array}$} & PRD & Ser afiliado \\
\hline & PRSC & Ser afiliado. \\
\hline & PLD & Ser afiliado. \\
\hline \multirow{3}{*}{ Uruguai } & PC & Ser afiliado. \\
\hline & PN & Ser afiliado. \\
\hline & FA & Ser afiliado. \\
\hline
\end{tabular}

Fonte: Textos Estatutários e Base de Dados Partidos Políticos de América Latina (1997-2000).

Recebido para publicação em maio de 2002 Tradução de Pedro Maia Soares 